\title{
Inhibition of mitochondrial reactive oxygen species improves coronary endothelial function after cardioplegic hypoxia/reoxygenation
}

Yi Song, MD, PhD, ${ }^{a}$ Hang Xing, MD, MSc, ${ }^{a}$ Yixin He, PhD, ${ }^{a}$ Zhiqi Zhang, MD, ${ }^{a}$ Guangbin Shi, MD, ${ }^{a}$ $\mathrm{Su} \mathrm{Wu}, \mathrm{MD},{ }^{\mathrm{a}}$ Yuhong Liu, MD, ${ }^{\mathrm{a}}$ Elizabeth O. Harrington, PhD, ${ }^{\mathrm{b}}$ Frank W. Sellke, MD, ${ }^{\mathrm{a}}$ and Jun Feng, MD, PhD, FAHA ${ }^{\mathrm{a}}$

\section{ABSTRACT}

Objective: Cardioplegic ischemia-reperfusion and diabetes mellitus are correlated with coronary endothelial dysfunction and inactivation of small conductance calcium-activated potassium channels. Increased reactive oxidative species, such as mitochondrial reactive oxidative species, may contribute to oxidative injury. Thus, we hypothesized that inhibition of mitochondrial reactive oxidative species may protect coronary small conductance calcium-activated potassium channels and endothelial function against cardioplegic ischemia-reperfusion-induced injury.

Methods: Small coronary arteries and endothelial cells from the hearts of mice with and without diabetes mellitus were isolated and examined by using a cardioplegic hypoxia and reoxygenation model to determine whether the mitochondriatargeted antioxidant Mito-Tempo could protect against coronary endothelial and small conductance calcium-activated potassium channel dysfunction. The microvessels or mouse heart endothelial cells were treated with or without Mito-Tempo (o-10 $\mu \mathrm{M}) 5$ minutes before and during cardioplegic hypoxia and reoxygenation. Microvascular function was assessed in vitro by vessel myography. $\mathrm{K}^{+}$currents of mouse heart endothelial cells were measured by whole-cell patch clamp. The levels of intracellular cytosolic free calcium $\left(\mathrm{Ca}^{2+}\right)$ concentration, mitochondrial reactive oxidative species, and small conductance calcium-activated potassium protein expression of mouse heart endothelial cells were measured by Rhod-2 fluorescence staining, MitoSox, and Western blotting, respectively.

Results: Cardioplegic hypoxia and reoxygenation significantly attenuated endothelial small conductance calcium-activated potassium channel activity, caused calcium overload, and increased mitochondrial reactive oxidative species of mouse heart endothelial cells in both the nondiabetic and diabetes mellitus groups. In addition, treating mouse heart endothelial cells with Mito-Tempo $(10 \mu \mathrm{M})$ reduced cardioplegic hypoxia and reoxygenation-induced $\mathrm{Ca}^{2+}$ and mitochondrial reactive oxidative species overload in both the nondiabetic and diabetes mellitus groups, respectively $(P<.05)$. Treatment with Mito-Tempo $(10 \mu \mathrm{M})$ significantly enhanced coronary relaxation responses to adenosine $5^{\prime}$-diphosphate and NS309 $(P<.05)$,

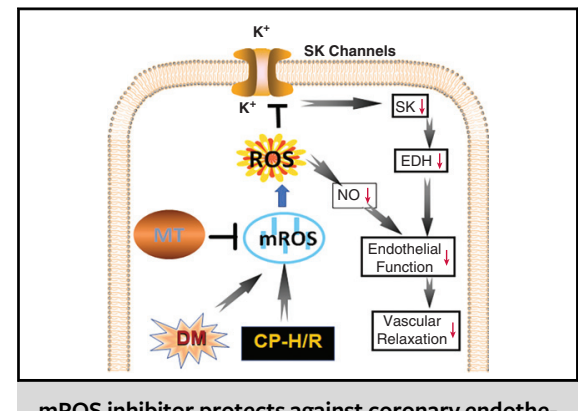

mROS inhibitor protects against coronary endothelial dysfunction after $\mathrm{CP}-\mathrm{H} / \mathrm{R}$.

\section{CENTRAL MESSAGE}

Inhibition of mROS with MT

protects coronary endothelial and SK channel function against CP-H/R injury in the mice with or without DM.

\section{PERSPECTIVE}

Inhibition of mROS with MT protects coronary endothelium-dependent relaxation and endothelial SK channel function against CP-H/R injury in the mice with or without DM. mROS inhibitors may be a new therapeutic agent for protecting coronary endothelial function during $C P-1 / R$ and cardiac surgery.

See Commentaries on pages e227 and e228.
From the ${ }^{\text {a} D i v i s i o n ~ o f ~ C a r d i o t h o r a c i c ~ S u r g e r y, ~ R h o d e ~ I s l a n d ~ H o s p i t a l, ~ A l p e r t ~ M e d i c a l ~}$ School of Brown University, Providence, RI; and ${ }^{\mathrm{b}}$ Department of Medicine, Vascular Research Laboratory, Providence VA Medical Center, Alpert Medical School of Brown University, Providence, RI

Date and number of Institutional Animal Care and Use Committee approval. Original approval date: 5/18/2018; newest approval date: 4/26/2021; internal reference number: 502118 (original), 501721 (new).

This research project was mainly supported by the National Institutes of Health 1R01HL127072-01A1, 1R01 HL136347-01, and National Institute of General Medical Sciences of 5P20-GM103652 (Pilot Project) to J.F., and 5P20GM103652 to E.O.H. and S.R. This work was supported in part by 3R01HL136347-04S1 to J.F., AHA-Grant-in-Aid (\#15GRNT25710105) to J.F., R01-HL46716 to F.W.S., and RO1HL128831 to F.W.S.
Y.S. and H.X. contributed equally to this article.

Received for publication Dec 13, 2020; revisions received May 16, 2021; accepted for publication June 10, 2021; available ahead of print June 26, 2021.

Address for reprints: Jun Feng, MD, PhD, FAHA, Cardiothoracic Surgery Research Laboratory, Rhode Island Hospital, 1 Hoppin St, Coro West Room 5.229, Providence, RI 02903 (E-mail: jfeng@lifespan.org).

0022-5223

Copyright (C) 2021 The Authors. Published by Elsevier Inc. on behalf of The American Association for Thoracic Surgery. This is an open access article under the CC BY-NC-ND license (http://creativecommons.org/licenses/by-nc-nd/4.0/).

https://doi.org/10.1016/j.jtcvs.2021.06.029 


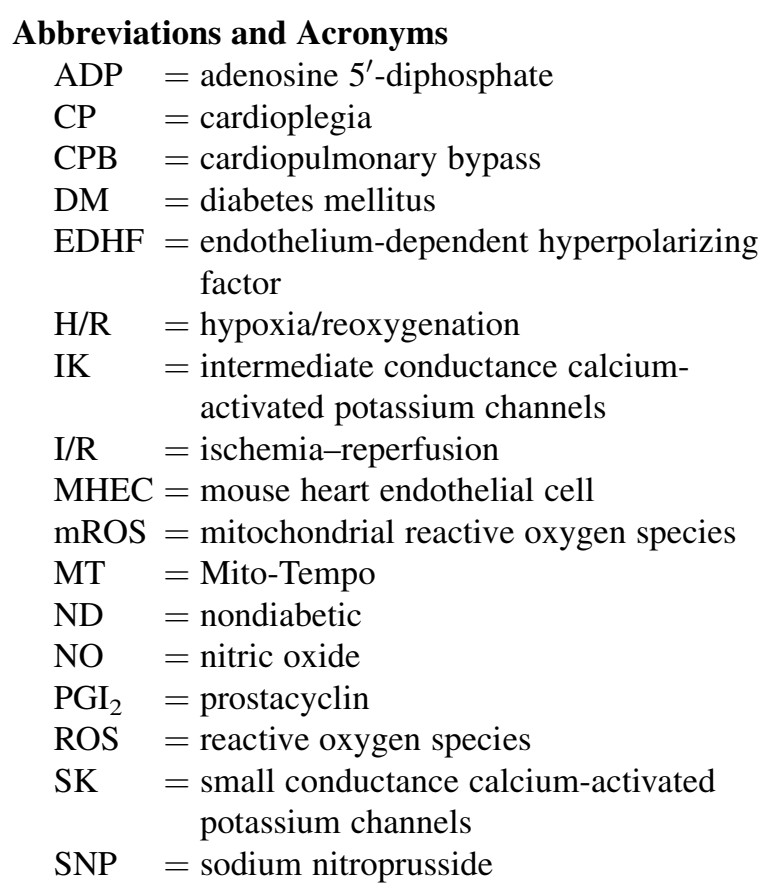

and endothelial small conductance calcium-activated potassium channel currents in both the nondiabetic and diabetes mellitus groups $(P<.05)$.

Conclusions: Administration of Mito-Tempo improves endothelial function and small conductance calciumactivated potassium channel activity, which may contribute to its enhancement of endothelium-dependent vasorelaxation after cardioplegic hypoxia and reoxygenation. (J Thorac Cardiovasc Surg 2022;164:(207-26)

Video clip is available online.

Cardioplegic $(\mathrm{CP})$ arrest and cardiopulmonary bypass $(\mathrm{CPB})$ are used to maintain the circulation during cardiac operations. ${ }^{1,2}$ Although the majority of heart-protection strategies have been shown to be safe and effective, $\mathrm{CP}$ ischemiareperfusion (I/R) injury still occurs during $\mathrm{CP} / \mathrm{CPB}$. $^{3,4}$ Vascular CP-I/R injury is manifested in part by diminished coronary endothelial function and impaired coronary relaxation, at times resulting in coronary spasm and myocardial malperfusion early after cardiac surgery. ${ }^{4-6}$ These disturbances appear to be more pronounced in patients with poorly controlled diabetes mellitus (DM). ${ }^{4,5,7,8}$ Endothelial cells are involved in various aspects of vessel function, including modulation of inflammation, prevention of coagulation, and preservation of the balance between vasodilatation and vasoconstriction. " Endothelial dysfunction is characterized by impaired vasodilation, which involves a number of endothelium-derived relaxing factors, including nitric oxide (NO), prostacyclin $\left(\mathrm{PGI}_{2}\right)$, and endothelialderived hyperpolarizing factors (EDHFs). ${ }^{10,11}$ The EDHFinduced endothelial hyperpolarization and vasodilation are mediated by small conductance calcium-activated potassium (SK) channels. ${ }^{12}$ Growing evidence indicates that SK channels also regulate $\mathrm{NO}$ and $\mathrm{PGI}_{2}$ in the endothelium. ${ }^{12-14}$ Endothelial dysfunction has been associated with impaired SK channel function. ${ }^{15}$ We and others have found that inactivation/inhibition of SK channels contributes to coronary endothelial dysfunction in animals and patients after CP-I/ $\mathrm{R}^{16}$ or CP hypoxia/reoxygenation (H/R). ${ }^{17,18}$ This effect on endothelial cells and the coronary vasculature is more pronounced in the setting of DM. ${ }^{18,19}$

Both $\mathrm{CP} / \mathrm{CPB}$ and DM can directly cause increased systemic oxidative stress, which results in organ, tissue, and cell damage after cardiac surgery. ${ }^{20,21}$ Oxidative stress consists of elevated intracellular levels of reactive oxygen species (ROS) that may lead to endothelial dysfunction. ${ }^{4,22}$ The excessive production of ROS suppresses the expression and function of endothelium-derived relaxing factors, resulting in impairment of endothelium-dependent vasorelaxation. ${ }^{7,23}$ The endothelial cells have an extensive mitochondrial network, ${ }^{24}$ suggesting that mitochondrial function may be important in response to the oxidative stress in the endothelium. Increased mitochondrial ROS (mROS) in the endothelium has been reported to play an important role in diabetes-induced endothelial dysfunction. ${ }^{19}$

Mito-Tempo (MT), which combines the antioxidant piperidine nitroxide (Tempo) with the lipophilic cation triphenylphosphonium, was recently reported to be a mitochondria-targeted antioxidant. ${ }^{25}$ This compound has been shown to protect the mitochondria from oxidative injury in various pathologies, such as endotoxin-induced liver injury, sepsis-induced acute kidney injury, hypertension, and colitis. ${ }^{26-29}$ However, few have investigated whether application of MT improves coronary endothelial function in the setting of CP-I/R and DM. Therefore, the objective of the present study was to use a CP-H/R model consisting of coronary endothelial cells and isolated small coronary arteries from mice with or without DM and to test whether MT can protect against $\mathrm{CP}-\mathrm{H} / \mathrm{R}$-induced coronary endothelial dysfunction and SK channel inhibition.

\section{MATERIALS AND METHODS}

\section{Animal and Mouse Heart Tissue Collection}

A total of 44 mice were used in the study, among which 22 C57BL/6J mice were used as nondiabetic (ND) controls (12-16 weeks old, male) and 22 BKS. Cg-Dock $7^{m}+/+$ Lepr $^{d b} / \mathrm{J}$ mice (12-16 weeks old, male) were studied as a model of DM (Jackson Laboratory, Bar Harbor, Me). 
All experiments were approved by the Institutional Animal Care and Use Committee of the Rhode Island Hospital. Each mouse was anesthetized by inhaled isoflurane after which a thoracotomy was performed. The heart was removed from the chest cavity. The hearts were placed in cold Krebs buffer for the in vitro microvascular experiments or preserved in cell culture medium in preparation for endothelial cell isolation. The surgical procedure of mouse heart tissue collection is detailed in Appendix E1.

\section{Experimental Groups}

For the microvessel study, 34 mice were divided into 6 groups for microvessel study: Group 1: ND mouse coronary microvessels were subjected to $\mathrm{CP}-\mathrm{H} / \mathrm{R}$ without MT treatment (ND [H/R], $\mathrm{n}=6$ ); Group 2: ND mouse coronary microvessels were subjected to CP-H/R with $1 \mu \mathrm{M}$ MT treatment ( $\mathrm{ND}[\mathrm{H} / \mathrm{R}]+1 \mu \mathrm{M} \mathrm{MT}, \mathrm{n}=5)$; Group 3: ND mouse microvessels were subjected to CP-H/R with $10 \mu \mathrm{M}$ MT treatment (ND [H/R] $+1 \mu \mathrm{M} \mathrm{MT}$, $n=6$ ); Group 4: DM mouse microvessels were subjected to $C P-H / R$ without MT treatment (DM $[\mathrm{H} / \mathrm{R}], \mathrm{n}=6)$; Group 5: DM mouse microvessels were subjected to CP-H/R with $1 \mu \mathrm{M}$ MT treatment $(\mathrm{DM}[\mathrm{H} / \mathrm{R}]+1 \mu \mathrm{M} \mathrm{MT,} \mathrm{n}=5)$; Group 6: DM mouse microvessels were subjected to $\mathrm{CP}-\mathrm{H} / \mathrm{R}$ with $10 \mu \mathrm{M}$ MT treatment (DM $[\mathrm{H} / \mathrm{R}]+10 \mu \mathrm{M} \mathrm{MT}, \mathrm{n}=6)$.

For the endothelial cell experiments, the other 10 mice (5 ND and 5 DM) were set for mouse heart endothelial cell (MHEC) isolation. The MHECs were labeled as 6 experimental groups: Group 1: ND MHECs without H/R or MT treatment (ND); Group 2: ND MHECs were subjected to H/R without MT treatment (ND [H/R]); Group 3: ND MHECs were subjected to $\mathrm{CP}-\mathrm{H} / \mathrm{R}$ with $10 \mu \mathrm{M}$ MT treatment (ND [H/R] $+10 \mu \mathrm{M}$ MT); Group 4: DM MHECs without H/R or MT treatment (DM); Group 5: DM MHECs were subjected to H/R without MT treatment (DM [H/R]); Group 6: DM MHECs were subjected to CP-H/R with $10 \mu \mathrm{M}$ MT treatment (DM [H/ $\mathrm{R}]+10 \mu \mathrm{M} \mathrm{MT}$ ). All the experiments on the cellular level were repeated at least 3 times. All experimental groups are shown in Figure E1.

\section{Microvessel Dissection and Cardioplegic Hypoxia/ \\ Reoxygenation Model of Microvessel}

The distal portion of left anterior descending artery (100-150 $\mu \mathrm{m}$ diameter) was dissected from the isolated mouse heart as previously described. ${ }^{18}$ An in vitro $\mathrm{CP}-\mathrm{H} / \mathrm{R}$ model of microvessel was used to simulate the ischemic cardiac arrest in the operating room. The $\mathrm{CP}$ solution, consisting of $110 \mathrm{NaCl}, 20 \mathrm{KCl}, 16 \mathrm{MgCl}_{2}, 1.5 \mathrm{CaCl}_{2}$, and $10 \mathrm{NaHCO}_{3}$ (in mM, pH 7.4) with or without MT ( $1 \mu \mathrm{M}$ or $10 \mu \mathrm{M}$, Enzo Life Sciences, Farmingdale, NY), replaced Krebs buffer for bathing the microvessel 5 minutes before hypoxia. After the pretreatment that simulates cardioplegia (CP) perfusion, the coronary arterioles were cooled in ice and set in the same solution for 60 minutes under hypoxic conditions $\left(5 \% \mathrm{CO}_{2}, 95 \% \mathrm{~N}_{2}\right)$. Then the vessel was reoxygenated $\left(95 \% \mathrm{O}_{2}, 5 \%\right.$ $\mathrm{CO}_{2}$ ) for another 60 minutes at $37^{\circ} \mathrm{C}$.

\section{Microvascular Vasodilation Assessment}

The microvessels were preconstricted with the thromboxane $\mathrm{A}_{2}$ analog U46619 $\left(4 \times 10^{-7} \mathrm{M}-10^{-6} \mathrm{M}\right)$ to reach a $30 \%$ to $40 \%$ reduction of the baseline diameter. After a stable constriction, microvascular relaxation was measured after using the following vasodilators: the SK channel activator NS309, the endothelium-dependent vasodilator adenosine $5^{\prime}$-diphosphate (ADP), ${ }^{16,18}$ and the endothelium-independent vasodilator sodium nitroprusside (SNP). The order of drugs was random with 1 or 2 interventions on each vessel. During each experiment, the responses to NS309 $\left(10^{-9}-10^{-5} \mathrm{M}\right), \operatorname{ADP}\left(10^{-9}-10^{-4} \mathrm{M}\right)$, and $\operatorname{SNP}\left(10^{-9}-10^{-4} \mathrm{M}\right)$ were recorded.

\section{Cardioplegic Hypoxia/Reoxygenation Model of Endothelial Cells}

MHECs isolated from the harvested heart were cultured in EGM-2 MV medium (Lonza Biosciences, Alpharetta, Ga), and the CP-H/R model of
MHECs was used according to previous study $^{18}$ (summarized in Appendix E1).

\section{Measurement of Intracellular Calcium}

The methods for measurement of intracellular $\mathrm{Ca}^{2+}$ of $\mathrm{MHECs}^{30,31}$ are detailed in Appendix E1.

\section{Electrophysiologic Study of Endothelial Cell $\mathrm{K}^{+}$ Currents}

Patch clamp recording techniques were used to measure $\mathrm{K}^{+}$currents in the whole cell patch-clamp configurations (Figure E2). Current-voltage recording conditions and current-time recording conditions for $\mathrm{K}^{+}$currents were achieved as described in detail previously ${ }^{15,18,19}$ and in Appendix E1. For $\mathrm{Ca}^{2+}$ free (low $\mathrm{Ca}^{2+}$ group) pipette solution, no $\mathrm{CaCl}_{2}$ was added. For median $\mathrm{Ca}^{2+}(400 \mu \mathrm{M})$ solution, $1.0 \mathrm{mM} \mathrm{CaCl}_{2}$ was used. For high $\mathrm{Ca}^{2+}$ $(2 \mu \mathrm{M})$ pipette solution, $9.7 \mathrm{mM} \mathrm{CaCl}_{2}$ was added. The Free $\mathrm{Ca}^{2+}$ concentration was calculated by using Maxchelator. ${ }^{30}$ The selective SK activator NS309 on the whole cell $\mathrm{K}^{+}$currents was examined, and then both SK2/ SK3 blocker apamin $\left(10^{-7} \mathrm{M}\right)$ and the SK4(IK) blocker TRAM34 $\left(10^{-6} \mathrm{M}\right)$ were applied for testing the specificity of SK channel activation. $^{15,18,19}$

\section{Western Blotting}

The methods for whole-cell protein purification, Western blotting, and imaging quantification have been described ${ }^{18,19}$ and are summarized in Appendix E1.

\section{Measurement of Mitochondrial Reactive Oxygen Species}

MHECs were stained with $5 \mu \mathrm{M}$ MitoSox Red and $100 \mathrm{nM}$ MitoTracker Green FM (Invitrogen, Waltham, Mass) according to the manufacturer's protocol and previously studied. ${ }^{19}$

\section{Chemicals}

ADP, apamin, NS309, and TRAM34 were purchased from Sigma-Aldrich (St Louis, Mo). MitoSox Red and MitoTracker Green FM were purchased from Invitrogen.

\section{Data Analysis}

All data are presented at the mean \pm standard deviation of the mean. Microvessel responses are expressed as the percent relaxation of the preconstricted diameter. The normality of data was assessed by the Shapiro-Wilk test. The data of microvascular reactivity, intracellular $\mathrm{Ca}^{2+}$ concentration, patch-clamp, SK protein expression, and mROS were analyzed using 1- or 2-way analysis of variance with post hoc tests by GraphPad Prism 7 (GraphPad Software, San Diego, Calif). Age, body weight, and blood glucose were analyzed using the paired $t$ test.

\section{RESULTS}

\section{Characteristics of Diabetic and Nondiabetic Mice}

The age of ND mice $(13.67 \pm 1.53$ weeks $)$ was not significantly different from that of DM mice (13.44 \pm 1.54 weeks). The body weight of the genetically modified DM mice $(46.83 \pm 3.64 \mathrm{~g})$ was greater than that of ND mice $(26.77 \pm 4.71 \mathrm{~g}, P<.01)$, and the blood glucose levels of DM mice $(692.1 \pm 17.80 \mathrm{mg} / \mathrm{dL})$ were higher than those of ND mice $(136.4 \pm 21.48 \mathrm{mg} / \mathrm{dL}, P<.01$, Figure E3). 

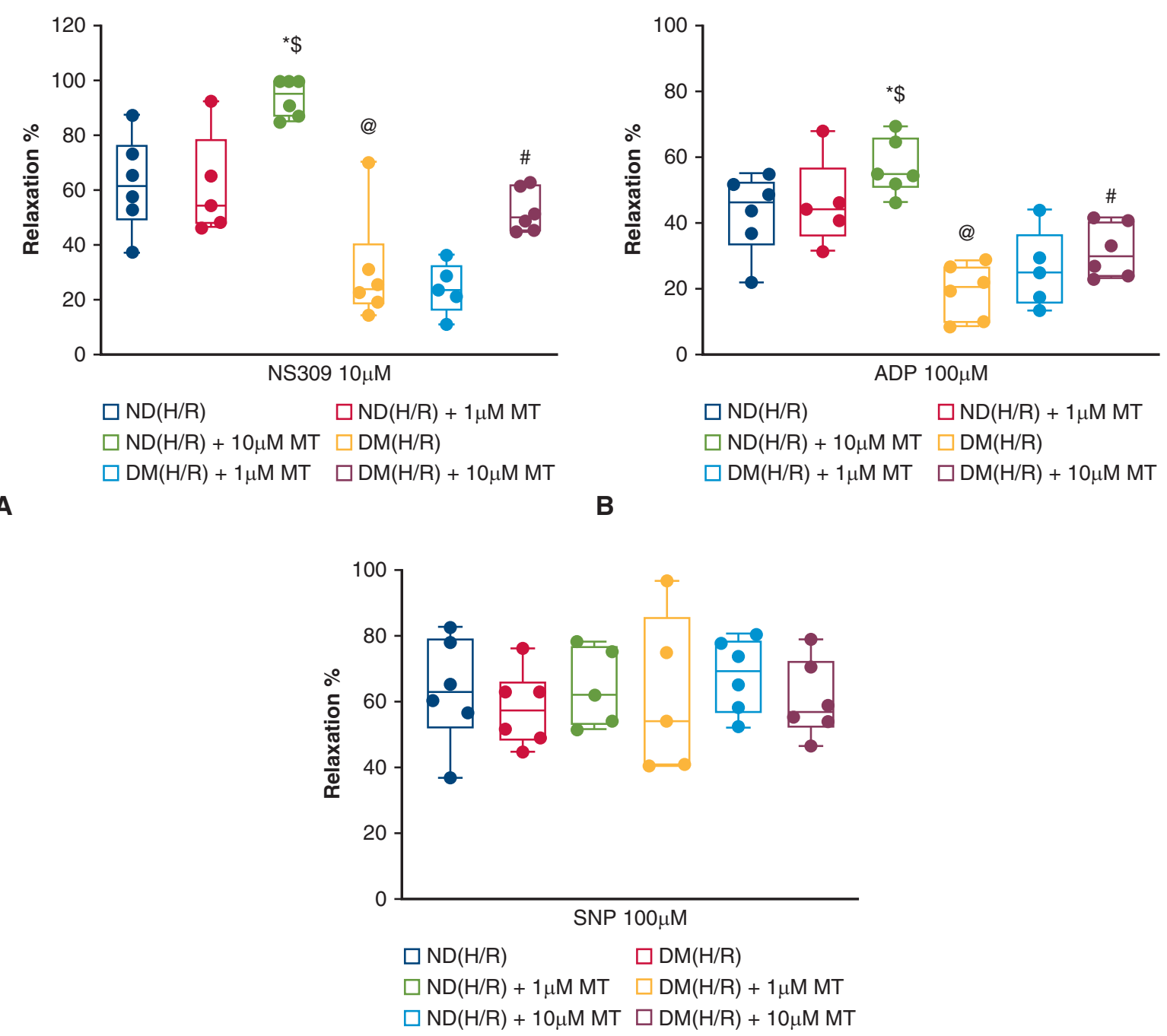

C

FIGURE 1. Dose-dependent effects of Mito-Tempo $(M T)$ treatment $(0-10 \mu \mathrm{M})$ on the recovery of relaxation responses of mouse small coronary arteries after CP-H/R. The diabetes $(D M)$ and nondiabetes $(N D)$ microvessels were preconstricted with the thromboxane $\mathrm{A}_{2}$ analog $\mathrm{U} 46619$ to reach a $30 \%$ to $40 \%$ reduction of the baseline diameter. After a stable constriction, microvascular relaxation in response to the SK activator NS309 (10 $\mu \mathrm{M})$ (A), ADP $(10 \mu \mathrm{M})(\mathrm{B})$, and SNP $(100 \mu \mathrm{M})(\mathrm{C})$ in the presence or absence of MT $(0-10 \mu \mathrm{M})$ was measured. ND $(\mathrm{H} / \mathrm{R})=\mathrm{ND}$ treated by hypoxia/reoxygenation; $\mathrm{ND}(\mathrm{H} / \mathrm{R})+1 \mu \mathrm{M} \mathrm{MT}=\mathrm{ND}(\mathrm{H} / \mathrm{R})$ treated with $1 \mu \mathrm{M}$ Mito-Tempo; ND $(\mathrm{H} / \mathrm{R})+10 \mu \mathrm{M} \mathrm{MT}=\mathrm{ND}(\mathrm{H} / \mathrm{R})$ treated with $10 \mu \mathrm{M}$ Mito-Tempo; DM (H/ $\mathrm{R})=\mathrm{DM}$ treated by hypoxia/reoxygenation; DM $(\mathrm{H} / \mathrm{R})+1 \mu \mathrm{M} \mathrm{MT}=\mathrm{DM}(\mathrm{H} / \mathrm{R})$ treated with $1 \mu \mathrm{M}$ Mito-Tempo; DM $(\mathrm{H} / \mathrm{R})+10 \mu \mathrm{M} \mathrm{MT}=\mathrm{DM}(\mathrm{H} /$ $\mathrm{R})$ treated with $10 \mu \mathrm{M}$ Mito-Tempo; $\mathrm{n}=5$-6/group; A, ${ }^{@} P=.0002$, ND $(\mathrm{H} / \mathrm{R})$ versus DM $(\mathrm{H} / \mathrm{R}) ; * P=.002, \mathrm{ND}(\mathrm{H} / \mathrm{R})+10 \mu \mathrm{M} \mathrm{MT}$ versus ND $(\mathrm{H} /$ $\mathrm{R}) ;{ }^{\#} P=.0329, \mathrm{DM}(\mathrm{H} / \mathrm{R})+10 \mu \mathrm{M}$ MT versus DM $(\mathrm{H} / \mathrm{R}) ;{ }^{\$} P<.0001, \mathrm{ND}(\mathrm{H} / \mathrm{R})+10 \mu \mathrm{M} \mathrm{MT}$ versus DM $(\mathrm{H} / \mathrm{R})+10 \mu \mathrm{M} \mathrm{MT} ; \mathrm{B},{ }^{@} P<.0001, \mathrm{ND}$ $(\mathrm{H} / \mathrm{R})$ versus DM $(\mathrm{H} / \mathrm{R}) ;{ }^{*} P=.0438, \mathrm{ND}(\mathrm{H} / \mathrm{R})+10 \mu \mathrm{M}$ MT versus ND $(\mathrm{H} / \mathrm{R}) ;{ }^{\#} P=.0293, \mathrm{DM}(\mathrm{H} / \mathrm{R})+10 \mu \mathrm{M} \mathrm{MT}$ versus DM $(\mathrm{H} / \mathrm{R}) ;{ }^{\$} P<.0001$, $\mathrm{ND}(\mathrm{H} / \mathrm{R})+10 \mu \mathrm{M}$ MT versus DM (H/R) $+10 \mu \mathrm{M} \mathrm{MT}$; mean \pm standard deviation (SD), 2-way analysis of variance (ANOVA) with a post hoc Bonferroni test. $H / R$, Hypoxia/reoxygenation; $A D P$, Adenosine 5'-diphosphate; $S N P$, sodium nitroprusside.

\section{Mito-Tempo Improved Endothelium-Dependent Relaxation Response After Cardioplegic Hypoxia/ Reoxygenation}

There was no significant difference in the baseline diameter of the microvessels among the 6 groups. The degrees of preconstriction by U46619 were $35.4 \% \pm 2.12 \%$ in the $\mathrm{ND}(\mathrm{H} / \mathrm{R})$ group, $36.4 \% \pm 1.66 \%$ in the ND $(\mathrm{H} / \mathrm{R})+1 \mu \mathrm{M}$ MT group,
$32.7 \% \pm 0.98 \%$ in the $\mathrm{ND}(\mathrm{H} / \mathrm{R})+10 \mu \mathrm{M}$ MT group, $36.0 \% \pm 2.4 \%$ in the $\mathrm{DM}(\mathrm{H} / \mathrm{R})$ group, $34.1 \% \pm 1.32 \%$ in the $\mathrm{DM}(\mathrm{H} / \mathrm{R})+1 \mu \mathrm{M}$ MT group, and $33.4 \% \pm 1.05 \%$ in the $\mathrm{DM}(\mathrm{H} / \mathrm{R})^{-}+10 \mu \mathrm{M}$ MT group $(P>.05$, respectively). The coronary vascular responses of DM (H/R) mice to the endothelium-dependent vasodilators NS309 $(10 \mu \mathrm{M})(P=.0002, \mathrm{ND}[\mathrm{H} / \mathrm{R}]$ vs DM $[\mathrm{H} / \mathrm{R}]$, Figure $1, A)$ and ADP $(100 \mu \mathrm{M})(P<.0001, \mathrm{ND}[\mathrm{H} / \mathrm{R}]$ vs 


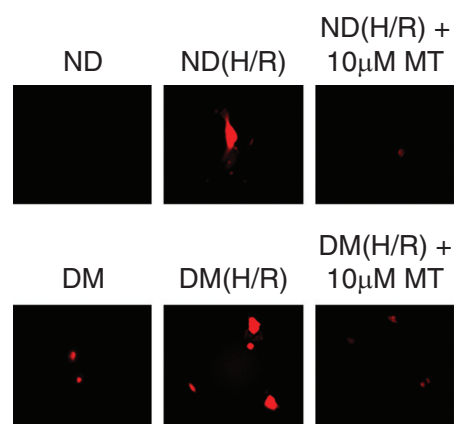

A

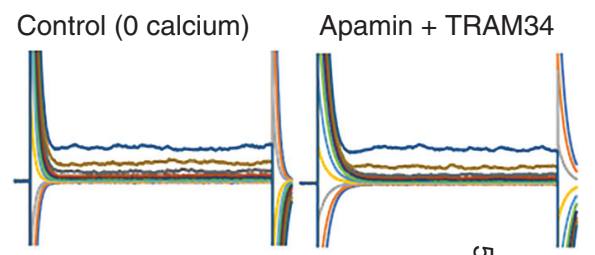

B

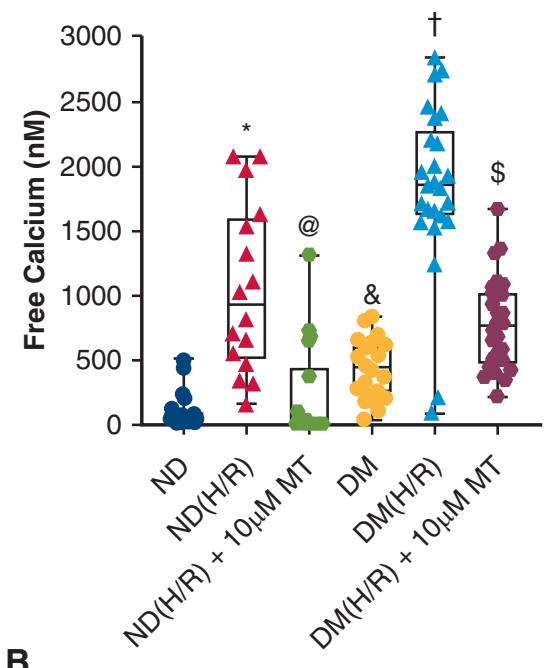

Control (400nM calcium)

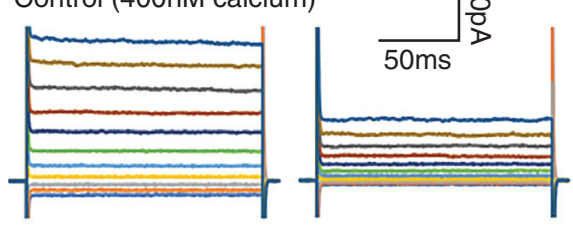

Control $(2 \mu \mathrm{M}$ calcium $)$
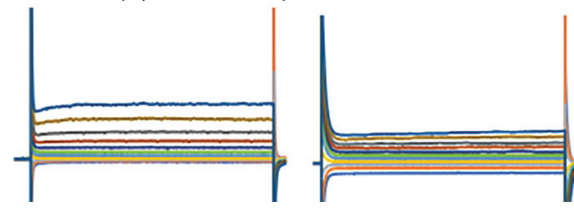

C

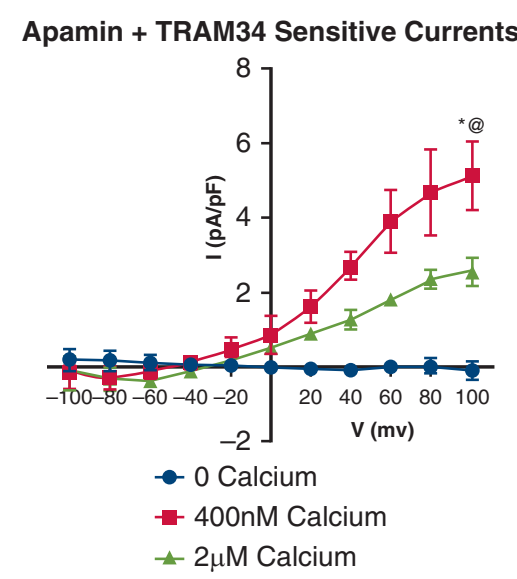

D

FIGURE 2. $\mathrm{H} / \mathrm{R}$ altered $\mathrm{Ca}^{2+}$ homeostasis in ND and DM mouse heart endothelial cells (MHECs). MHECs were isolated from DM or ND mice. A, Representative fluorescent of intracellular calcium $\left(\mathrm{Ca}^{2+}\right)$ of MHECs treated with or without Mito-Tempo $(M T)(10 \mu \mathrm{M})$. B, Quantitative analysis of intracellular $\mathrm{Ca}^{2+}$ concentration changes of MHECs in the following experimental groups: ND, $\mathrm{n}=22 ; \mathrm{ND}(\mathrm{H} / \mathrm{R}), \mathrm{n}=16 ; \mathrm{ND}(\mathrm{H} / \mathrm{R})+10 \mu \mathrm{M} \mathrm{MT}, \mathrm{n}=18 ; \mathrm{DM}, \mathrm{n}=20$; $\mathrm{DM}(\mathrm{H} / \mathrm{R}), \mathrm{n}=25 ; \mathrm{DM}(\mathrm{H} / \mathrm{R})+10 \mu \mathrm{M} \mathrm{MT}, \mathrm{n}=28 ; * P<.0001, \mathrm{ND}(\mathrm{H} / \mathrm{R})$ versus ND; ${ }^{\circledR} P<.0001, \mathrm{ND}(\mathrm{H} / \mathrm{R})+10 \mu \mathrm{M} \mathrm{MT}$ versus ND $(\mathrm{H} / \mathrm{R}) ;{ }^{\&} P<.0001$, DM versus ND; ${ }^{\dagger} P<.0001, \mathrm{DM}(\mathrm{H} / \mathrm{R})$ versus DM; ${ }^{\$} P<.0001, \mathrm{DM}(\mathrm{H} / \mathrm{R})+10 \mu \mathrm{M}$ MT versus DM (H/R). C, Representative traces of the whole cell currents of MHECs with different free calcium concentration. D, The plots show Apamin + TRAM34-sensitive component of $\mathrm{K}^{+}$current at $+100 \mathrm{mV}(0 \mathrm{calcium}$, $\left.\mathrm{n}=4 ; 400 \mathrm{nM} \mathrm{Ca}^{2+}, \mathrm{n}=3 ; 2 \mu \mathrm{M} \mathrm{Ca}^{2+}, \mathrm{n}=3\right), * P<.0001,400 \mathrm{nM} \mathrm{Ca}^{2+}$ versus $0 \mathrm{Ca}^{2+} ;{ }^{@} P<.0001,400 \mathrm{nM} \mathrm{Ca}^{2+}$ versus $2 \mu \mathrm{M} \mathrm{Ca}^{2+} ;$ mean $\pm \mathrm{SD}, \mathrm{ND}$ $(\mathrm{H} / \mathrm{R})=\mathrm{ND}$ treated by hypoxia/reoxygenation; DM $(\mathrm{H} / \mathrm{R})=\mathrm{DM}$ treated by hypoxia/reoxygenation; ND $(\mathrm{H} / \mathrm{R})+10 \mu \mathrm{M}$ MT $=\mathrm{ND}(\mathrm{H} / \mathrm{R})$ treated with10 $\mu \mathrm{M}$ Mito-Tempo; DM (H/R) $+10 \mu \mathrm{M}$ MT $=\mathrm{DM}(\mathrm{H} / \mathrm{R})$ treated with $10 \mu \mathrm{M}$ Mito-Tempo; mean $\pm \mathrm{SD}$, 1-way ANOVA with a post hoc Dunnett's multiple comparison test. $N D$, Nondiabetic; $H / R$, hypoxia/reoxygenation; $D M$, diabetes mellitus.

DM $[\mathrm{H} / \mathrm{R}]$, Figure $1, B)$ were significantly decreased compared with the ND (H/R) group, respectively. The effect of MT on improvement of vasodilation after CP-H/R is dose dependent. Treatment with $10 \mu \mathrm{M}$ MT significantly improved NS309 $(10 \mu \mathrm{M}) \quad(P=.002, \quad \mathrm{ND} \quad[\mathrm{H} /$ $\mathrm{R}]+10 \mu \mathrm{M}$ MT vs ND $[\mathrm{H} / \mathrm{R}] ; P=.0329, \mathrm{DM}$ $[\mathrm{H} / \mathrm{R}]+10 \mu \mathrm{M}$ MT vs DM [H/R], Figure $1, A)$ and ADP $(100 \mu \mathrm{M})(P=.0438, \mathrm{ND}[\mathrm{H} / \mathrm{R}]+10 \mu \mathrm{M}$ MT vs ND $[\mathrm{H} / \mathrm{R}] ; P=.0293, \mathrm{DM}[\mathrm{H} / \mathrm{R}]+10 \mu \mathrm{M}$ MT vs DM $[\mathrm{H} / \mathrm{R}]$,
Figure $1, B)$ induced relaxation in both ND $(\mathrm{H} / \mathrm{R})$ and DM $(H / R)$ vessels, respectively. In contrast, treatment with $1 \mu \mathrm{M}$ MT failed to affect NS309 (Figure 1, A) and ADP (Figure 1, $B$ ) induced relaxation response $(P>.05)$. There were no statistical differences in the vascular responses to SNP among the 6 groups $(P>.05$, Figure $1, C)$. The data of dose-dependent vasodilatory effects of NS309, ADP, and SNP are summarized in Figure E4. 

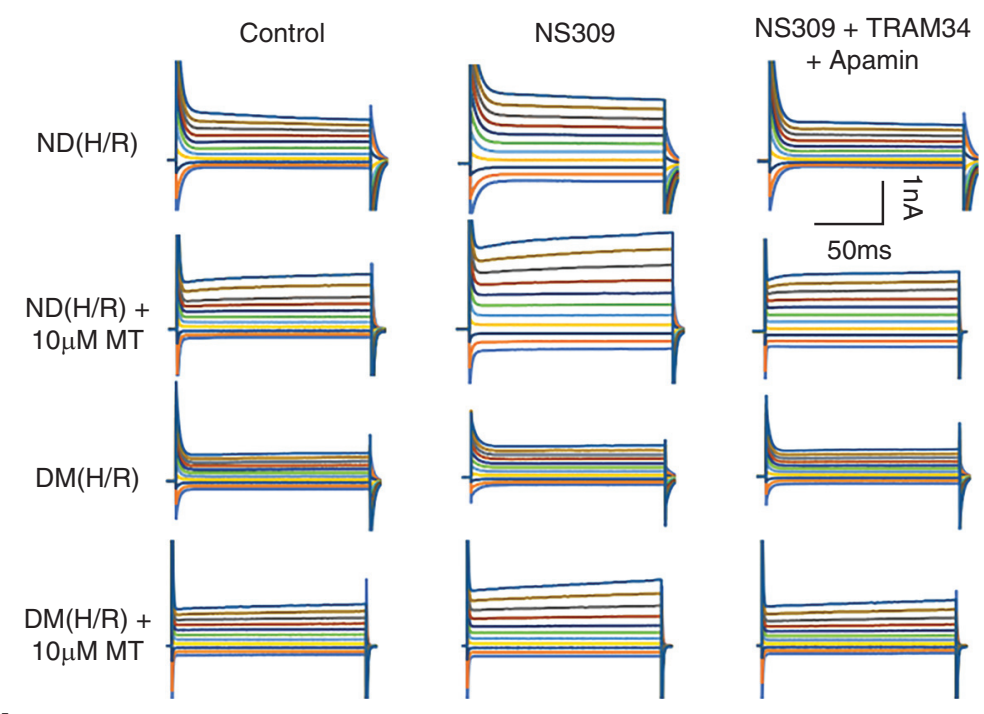

A

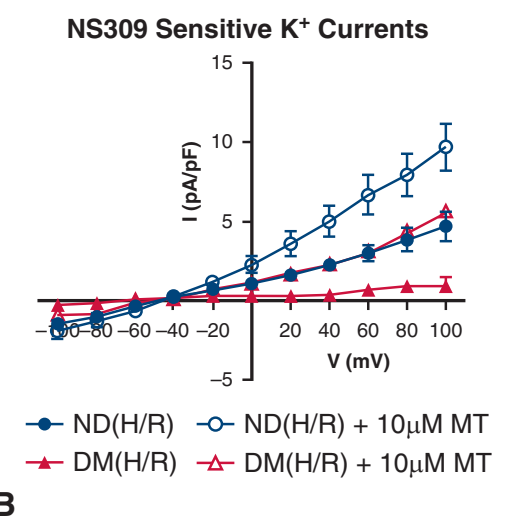

Apamin + TRAM34 Sensitive $\mathrm{K}^{+}$Currents
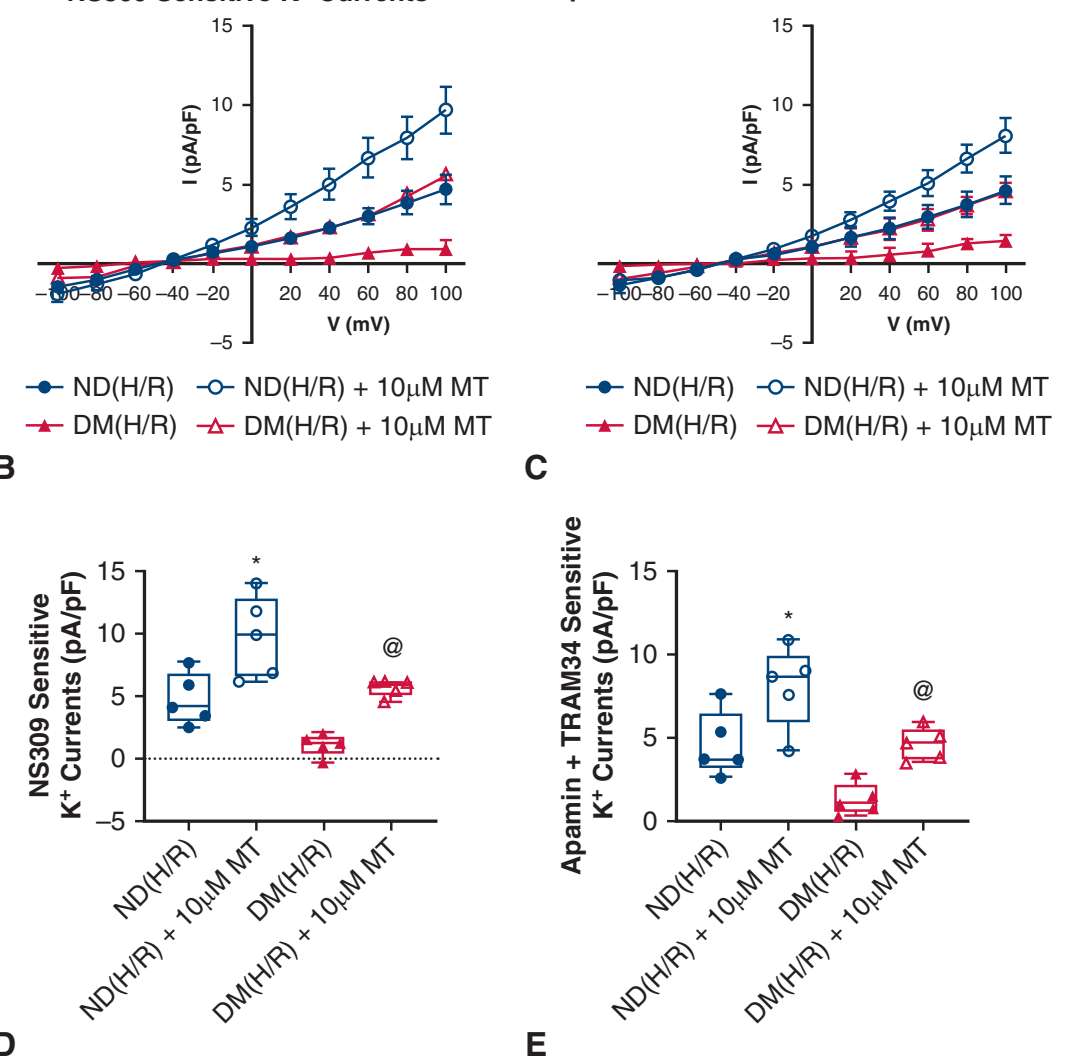

FIGURE 3. MT significantly increases SK channel currents of MHECs in $H / R$ model from ND and DM mice. A, Representative traces of the whole cell currents of MHECs treated with or without MT $(10 \mu \mathrm{M})$ at holding potential of $-50 \mathrm{mV}$ and test potentials from -100 to $+100 \mathrm{mV}$ in $20 \mathrm{mV}$ increments. B, Whole-cell I-V relationships sensitive to NS309 in MHECs of ND (H/R) and DM (H/R) mice with or without MT treatment. C, Whole cell I-V relationships sensitive to TRAM34+Apamin in MHECs of ND (H/R) and DM (H/R) with or without MT treatment. D, Box plots show NS309-sensitive component of potassium current at $+100 \mathrm{mV}$ in ND $(\mathrm{H} / \mathrm{R})$ and $\mathrm{DM}(\mathrm{H} / \mathrm{R})$ MHECs treated with or without MT $(\mathrm{n}=5 /$ group$) . * P=.0074, \mathrm{ND}(\mathrm{H} / \mathrm{R})+10 \mu \mathrm{M} \mathrm{MT}$ versus $\mathrm{ND}(\mathrm{H} / \mathrm{R}) ;{ }^{@} P=.0162, \mathrm{DM}(\mathrm{H} / \mathrm{R})+10 \mu \mathrm{M}$ MT versus DM (H/R). E, Box plots showing TRAM34+Apamin-sensitive component of potassium current at $+100 \mathrm{mV}$ in ND $(\mathrm{H} / \mathrm{R})$ and DM $(\mathrm{H} / \mathrm{R})$ MHECs treat with or without MT $(\mathrm{n}=5 /$ group $) . * P=.0322, \mathrm{ND}(\mathrm{H} / \mathrm{R})+10 \mu \mathrm{M}$ MT versus ND $(\mathrm{H} / \mathrm{R}) ;{ }^{@} P=.0451$, $\mathrm{DM}(\mathrm{H} / \mathrm{R})+10 \mu \mathrm{M}$ MT versus DM (H/R). ND $(\mathrm{H} / \mathrm{R})=\mathrm{ND}$ treated by hypoxia/reoxygenation; $\mathrm{DM}(\mathrm{H} / \mathrm{R})=\mathrm{DM}$ treated by hypoxia/reoxygenation; ND $(\mathrm{H} / \mathrm{R})+10 \mu \mathrm{M} \mathrm{MT}=\mathrm{ND}(\mathrm{H} / \mathrm{R})$ treated with $10 \mu \mathrm{M}$ Mito-Tempo; DM (H/R) $+10 \mu \mathrm{M} \mathrm{MT}=\mathrm{DM}(\mathrm{H} / \mathrm{R})$ treated with $10 \mu \mathrm{M}$ Mito-Tempo; mean $\pm \mathrm{SD}, 1$ way ANOVA with a post hoc Sidak's multiple comparison test. $N D$, Nondiabetic; $H / R$, hypoxia/reoxygenation; $M T$, Mito-Tempo; $D M$, diabetes mellitus. 


\section{Mito-Tempo Suppressed Intracellular $\mathrm{Ca}^{2+}$ After Cardioplegic Hypoxia/Reoxygenation}

After CP-H/R, MHECs in ND (H/R) and DM (H/R) showed significantly higher intracellular free $\mathrm{Ca}^{2+}$ concentration than the baseline (ND or DM) $(P<.0001$, Figure $2, A$ and $B)$. MT $(10 \mu \mathrm{M})$ treatment significantly suppressed intracellular $\mathrm{Ca}^{2+}$ concentration in $\mathrm{ND}(\mathrm{H} / \mathrm{R})+10 \mu \mathrm{M}$ MT and $\mathrm{DM}$ $(\mathrm{H} / \mathrm{R})+10 \mu \mathrm{M}$ MT groups compared with ND (H/R) and $\mathrm{DM}(\mathrm{H} / \mathrm{R})$ groups $(P<.0001$, Figure $2, A$ and $B)$.

\section{Biphasic Effects of Intracellular $\mathrm{Ca}^{2+}$ on Endothelial Small Conductance Calcium-Activated Potassium Channel Currents}

To investigate whether intracellular $\mathrm{Ca}^{2+}$ affects endothelial SK currents, we examined the effects of the low concentration $\mathrm{Ca}^{2+}$-free $(0)$, median concentration $\mathrm{Ca}^{2+}(400 \mathrm{nM})$, and high concentration free $\mathrm{Ca}^{2+}(2 \mu \mathrm{M})$ by recording whole-cell apamin + TRAM34-sensitive currents. The SK channel currents were highly activated at median $\mathrm{Ca}^{2+}$ yet inhibited at high $\mathrm{Ca}^{2+}$ and inactivated at $\mathrm{Ca}^{2+}$ free (Figure 2, $C$ and $D$ ), suggesting that intracellular $\mathrm{Ca}^{2+}$ has a biphasic effect on endothelial SK currents.

\section{Mito-Tempo Increased Endothelial Small}

\section{Conductance Calcium-Activated Potassium Channel} Currents After Cardioplegic Hypoxia/Reoxygenation

Administration of NS309 significantly increased the total $\mathrm{K}^{+}$currents of MHECs. Acute MT treatment significantly increased NS309 sensitive currents in the CP-H/R model of $\mathrm{ND}$ and DM mice $(P=.0074, \mathrm{ND}[\mathrm{H} / \mathrm{R}]+10 \mu \mathrm{M}$ vs ND $[\mathrm{H} / \mathrm{R}] ; P=.0162, \mathrm{DM}[\mathrm{H} / \mathrm{R}]+10 \mu \mathrm{M}$ vs $\mathrm{DM}[\mathrm{H} / \mathrm{R}]$; Figure $3, A, B$, and $D$ ). Subsequent application of apamin and TRAM34 abolished NS309-sensitive $\mathrm{K}^{+}$currents in both groups (Figure 3, $A, C$, and $E$ ). The MT $(10 \mu \mathrm{M})$ treatment significantly increased SK (apamin + TRAM34 sensitive) channel currents in ND and DM MHECs $(P=.0322$, ND $[\mathrm{H} / \mathrm{R}]+10 \mu \mathrm{M}$ MT vs ND $[\mathrm{H} / \mathrm{R}] ; P=.0451$, DM $[\mathrm{H} / \mathrm{R}]+10 \mu \mathrm{M}$ MT vs DM [H/R]; Figure 3, $A, C$, and $E$ ). This effect of MT was more pronounced in ND mice $(\mathrm{H} / \mathrm{R})+10 \mu \mathrm{M} \quad \mathrm{MT}$ than $\mathrm{DM}$ mice $(\mathrm{H} / \mathrm{R})+10 \mu \mathrm{M}$ MT $(P<.05$, Figure 3$)$. In the series of time-current relationship experiments, the similar effects of MT $(10 \mu \mathrm{M})$ treatment in ND (H/R) $+10 \mu \mathrm{M}$ MT and DM $(\mathrm{H} / \mathrm{R})+10 \mu \mathrm{M}$ MT groups were observed by showing noticeably increased in SK currents compared with the non-MT treatment groups (Figure 4). The data of IV relationship for NS309 and apamin + TRAM34 sensitive currents within each cell/ treatment group are summarized in Figure E5.

\section{Effects of Hypoxia/Reoxygenation and Mito-Tempo Treatment on Small Conductance Calcium-Activated Potassium Channel Protein Expression}

There were no significant differences between the ND and DM groups at baseline in the SK3 and SK4 protein expression of the MHECs (Figure 5, $P>.05$ ). Neither H/R nor MT treatment altered endothelial SK3 and SK4 expression in the ND or DM group.

\section{Mito-Tempo Reduced Mitochondrial Reactive Oxygen Species Production After Cardioplegic Hypoxia/Reoxygenation}

Under normoxic conditions, DM MHECs exhibited clearly higher levels of mROS than their ND counterparts $(P<.0001$, Figure 6). CP-H/R further increased $\mathrm{mROS}$ in both ND $(\mathrm{H} / \mathrm{R})$ and $\mathrm{DM}$ mice $(\mathrm{H} / \mathrm{R})(P<.0001$, Figure 6). In ND (H/R) $+10 \mu \mathrm{M}$ MT, the treatment with MT notably reduced mROS $(P<.0001$, Figure 6$)$. Likewise, MT treatment substantially reduced mROS in DM mice $(\mathrm{H} / \mathrm{R})+10 \mu \mathrm{M}$ MT $(P<.0001$, Figure 6$)$.

\section{DISCUSSION}

There are a number of novel findings in the current study. First, CP-H/R induced a significant increase in endothelial mROS, and this was more profound in the DM endothelial cells than in the ND endothelial cells. Second, MT $(10 \mu \mathrm{M})$ treatment significantly inhibited endothelial mROS. Third, $\mathrm{CP}-\mathrm{H} / \mathrm{R}$ caused intracellular $\mathrm{Ca}^{2+}$ overload in both ND and DM endothelial cells accompanied by impairment of SK channel activity. Fourth, administration of MT $(10 \mu \mathrm{M})$ enhanced endothelial SK channel activity of ND and $\mathrm{DM}$ in the setting of $\mathrm{CP}-\mathrm{H} / \mathrm{R}$. Finally, treatment of small coronary artery with MT in the setting of $\mathrm{CP}-\mathrm{H} /$ $\mathrm{R}$ improved the endothelium-dependent relaxation in response to the SK activator NS309 and the endothelium-/NO-dependent vasodilator ADP in both ND and DM mice, and these effects were MT dose-dependent.

The vascular endothelium has a critical role in vasomotor regulation, maintenance of tissue perfusion, and prevention of vascular thrombosis. $\mathrm{CP}$ has been associated with marked endothelial dysfunction ${ }^{4,6,7,31}$ and marked changes in myocardial perfusion in vivo. ${ }^{32}$ Several mechanisms, such as increased oxidative stress, leukocyte, and complement activation, contribute to this dysfunction. ${ }^{4,31,33}$ As mentioned previously, poorly controlled DM has been reported to be an important predisposing factor to endothelial dysfunction in previous clinical studies. ${ }^{5,7}$ Furthermore, in addition to altered myocardial perfusion, vascular spasm, and electrocardiogram changes in the perioperative period, endothelial dysfunction can lead to intimal hyperplasia and aggressive atherosclerosis that may arise weeks or year after surgery. Thus, novel strategies to protect the coronary endothelium in the setting of cardiovascular surgery, such as the inhibition of mROS as presented in this study, have considerable short-term and long-term clinical implications.

ROS are formed as a natural by-product of the normal metabolism of oxygen and have important roles in cell 
$\mathrm{ND}(\mathrm{H} / \mathrm{R})$

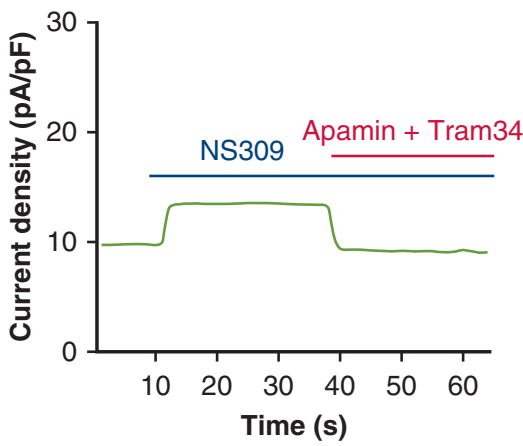

A

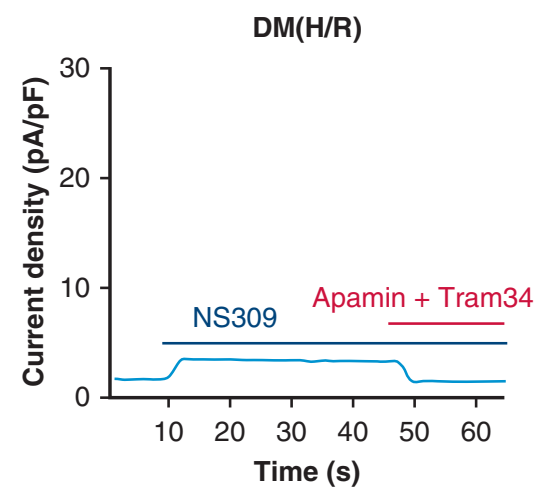

C

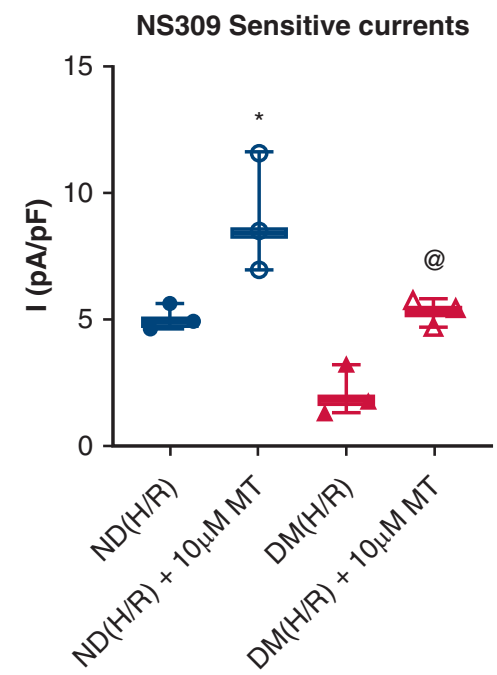

E

FIGURE 4. MT significantly increases SK channel currents of MHECs in H/R model from ND and DM mice. A-D, Time course of the whole-cell current density evoked at $+100 \mathrm{mV}$ from MHECs using patch clamp. NS309 was added to the bath to activated SK/IK channels, followed by bath application of Apamin and TRAM34 to block them. E, Box plots shows NS309-sensitive component of potassium current at $+100 \mathrm{mV}$ in ND (H/R) and DM (H/R) MHECs treat with or without MT $(\mathrm{n}=3 /$ group $) ; * P=.0486, \mathrm{ND}(\mathrm{H} / \mathrm{R})+10 \mu \mathrm{M}$ MT versus ND $(\mathrm{H} / \mathrm{R}) ;{ }^{\circledR} P=.0082, \mathrm{DM}(\mathrm{H} / \mathrm{R})+10 \mu \mathrm{M} \mathrm{MT}$ versus DM $(\mathrm{H} / \mathrm{R}) . \mathrm{F}$, Box plots show Apamin + TRAM34-sensitive component of potassium current at $+100 \mathrm{mV}$ in ND (H/R) and DM (H/R) MHECs treat with or without MT $\left(\mathrm{n}=3\right.$ /group). $* P=.0233, \mathrm{ND}(\mathrm{H} / \mathrm{R})+10 \mu \mathrm{M}$ MT versus ND $(\mathrm{H} / \mathrm{R}) ;{ }^{\circledR} P=.0203, \mathrm{DM}(\mathrm{H} / \mathrm{R})+\mathrm{MT}$ versus DM $(\mathrm{H} / \mathrm{R}) ; \mathrm{ND}(\mathrm{H} / \mathrm{R})=\mathrm{ND}$ treated by hypoxia/reoxygenation; ND $(\mathrm{H} / \mathrm{R})+10 \mu \mathrm{M} \mathrm{MT}=\mathrm{ND}(\mathrm{H} / \mathrm{R})$ treated with $10 \mu \mathrm{M}$ Mito-Tempo; DM $(\mathrm{H} / \mathrm{R})=$ DM treated by hypoxia/reoxygenation; $\mathrm{DM}(\mathrm{H} / \mathrm{R})+10 \mu \mathrm{M} \mathrm{MT}=\mathrm{DM}(\mathrm{H} / \mathrm{R})$ treated with $10 \mu \mathrm{M}$ Mito-Tempo; mean $\pm \mathrm{SD}$, 1-way ANOVA with Student $t$ test. $N D$, Nondiabetic; $H / R$, hypox$\mathrm{ia} /$ reoxygenation; $M T$, Mito-Tempo; $D M$, diabetes mellitus.

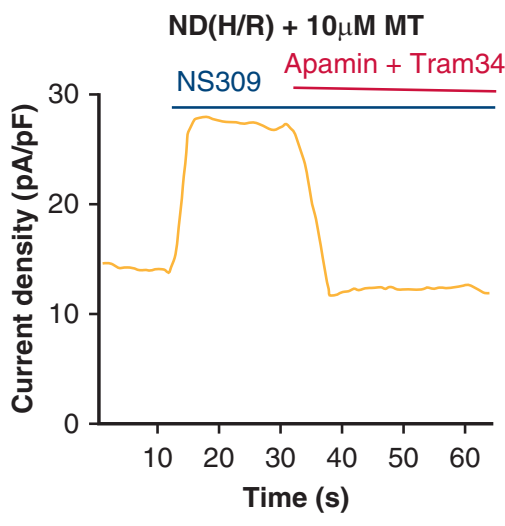

B

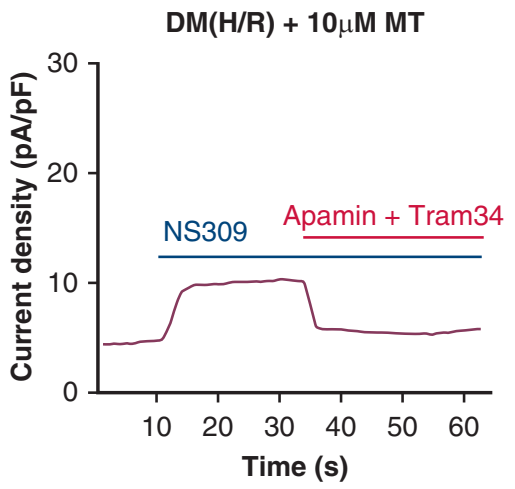

APAMIN + TRAM34 Sensitive currents
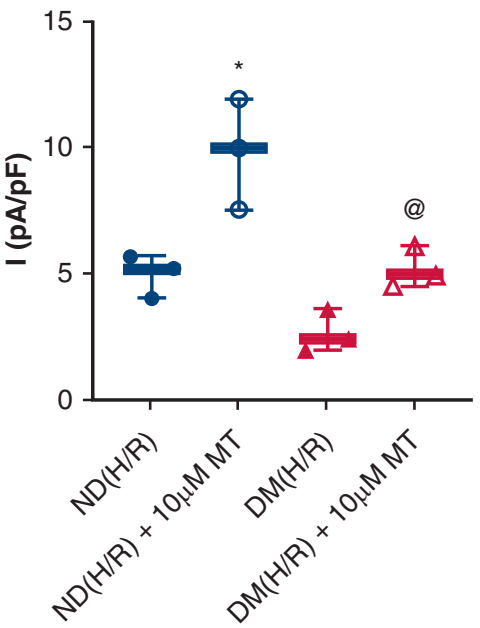

$\mathbf{F}$ 


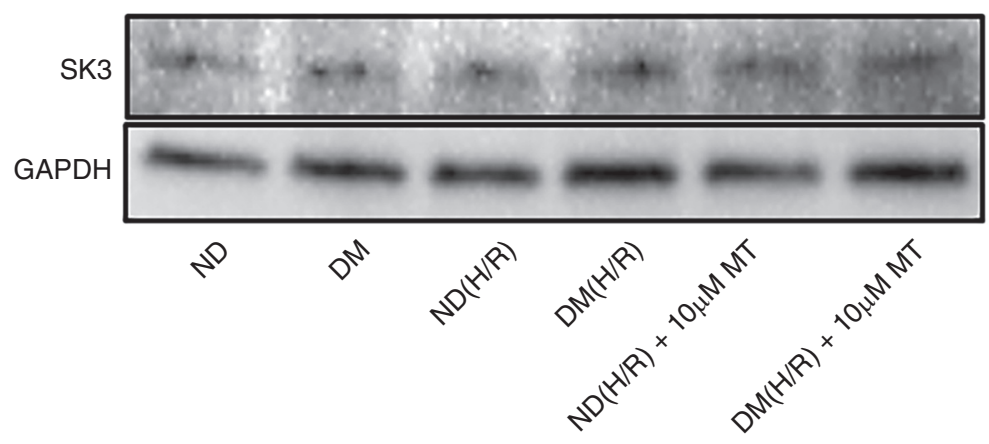

A

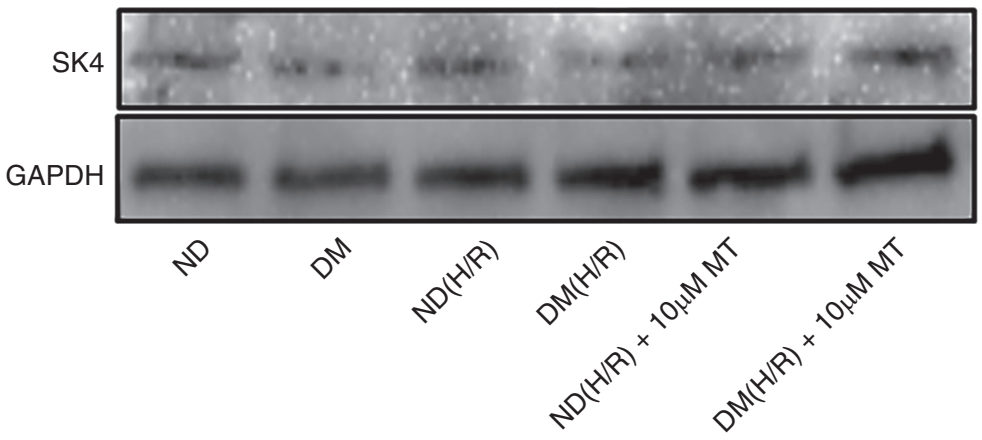

B
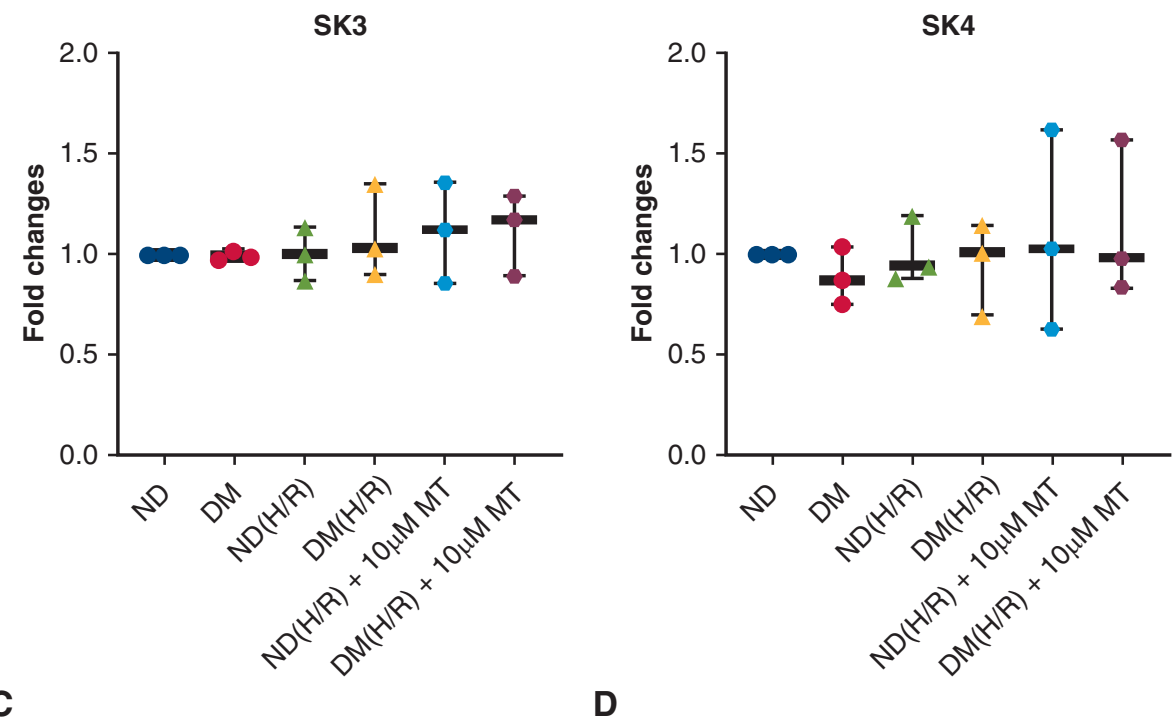

FIGURE 5. H/R and MT treatment failed to effect SK3 and SK4 protein expression in MHECs. A and B, Immunoblot intensity of SK, SK3 (A), SK4 (B) with a GAPDH loading control; $\mathrm{C}$ and D, graphs showing densitometric analysis of immunoband intensity of SK3 (C) and SK4 (D) protein expression in the experimental groups. ND $(\mathrm{H} / \mathrm{R})=\mathrm{ND}$ cells treated by hypoxia/reoxygenation. DM $(\mathrm{H} / \mathrm{R})=\mathrm{DM}$ cells treated by hypoxia/reoxygenation; ND $(\mathrm{H} / \mathrm{R})+10 \mu \mathrm{M}$ MT, ND (H/R) cells treated with $10 \mu \mathrm{M} \mathrm{MT}$; DM $(\mathrm{H} / \mathrm{R})+10 \mu \mathrm{M}$ MT, DM (H/R) cells treated with $10 \mu \mathrm{M}$ MT; n $=3 /$ group. Mean $\pm \mathrm{SD}, 1$-way ANOVA, and post hoc Bonferroni test. $N D$, Nondiabetic; $H / R$, hypoxia/reoxygenation; $M T$, Mito-Tempo; $D M$, diabetes mellitus.

signaling, metabolic adaptation, inflammatory response, and homeostasis. ${ }^{34-36}$ However, the unbalanced ROS production may induce oxidative damage that has been implicated in the pathogenesis of a variety of disorders, including DM and its complications. Furthermore, accumulated evidence has indicated that the generation of
ROS is a major cause of endothelial injury after CP-I/R. ${ }^{37}$ The mitochondrion is the main source of ROS generation. ${ }^{24}$ $\mathrm{CP}-\mathrm{H} / \mathrm{R}$ caused a significant increase in endothelial mROS with or without DM. MT is a physicochemical compound as one of the manganese superoxide dismutase mimics, which can pass through lipid bilayers easily and accumulate 


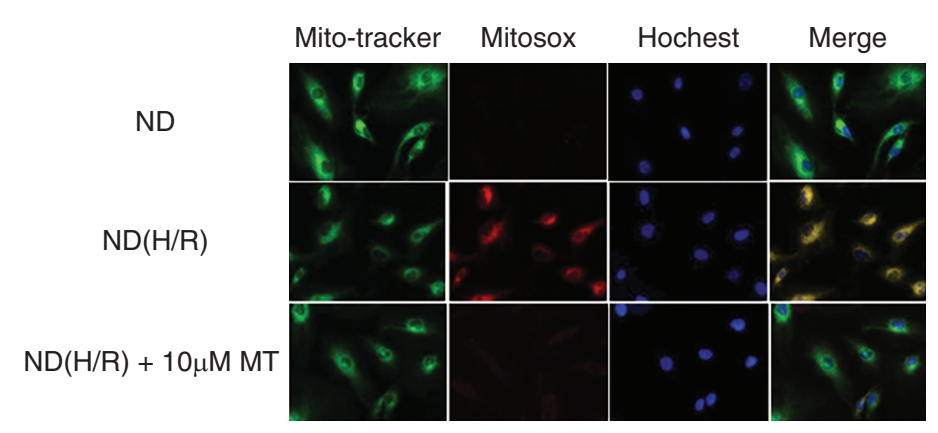

A

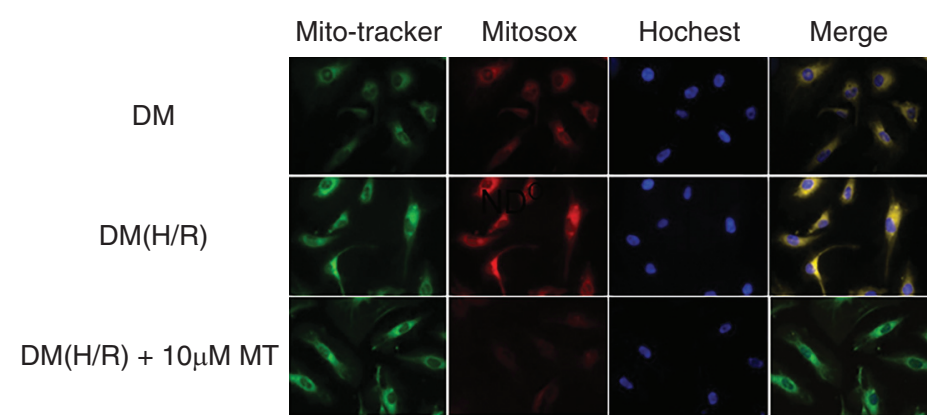

B

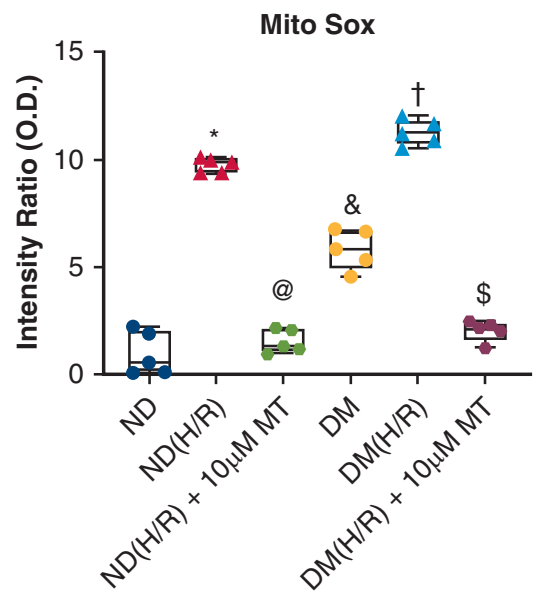

FIGURE 6. The effects of MT on the production of mROS induced by H/Rin ND and DM MHECs. Mitochondria localization was visualized using MitoTracker and mROS production was monitored with MitoSOX after exposure to MT induced by H/R in ND (A) and DM (B) MHECs. C, Box plots summarizing the data analysis of mROS in the experimental groups, $\mathrm{n}=5$ /group. $* P<.0001, \mathrm{ND}(\mathrm{H} / \mathrm{R})$ versus ND; ${ }^{@} P<.0001, \mathrm{ND}$ (H/R) $+\mathrm{MT}$ versus $\mathrm{ND}(\mathrm{H} / \mathrm{R}) ;{ }^{\circledR} P<.0001, \mathrm{DM}$ versus ND; ${ }^{\dagger} P<.0001, \mathrm{DM}(\mathrm{H} / \mathrm{R})$ versus DM; ${ }^{\$} P<.0001, \mathrm{DM}(\mathrm{H} / \mathrm{R})+10 \mu \mathrm{M}$ MT versus DM $(\mathrm{H} / \mathrm{R}) . \mathrm{ND}=\mathrm{ND}$ cells under normoxic condition; $\mathrm{DM}=\mathrm{DM}$ cells under normoxic condition; ND $(\mathrm{H} / \mathrm{R})=\mathrm{ND}$ treated by hypoxia/reoxygenation; $\mathrm{DM}(\mathrm{H} / \mathrm{R})=\mathrm{DM}$ cells under hypoxia/reoxygenation; ND (H/R) $+10 \mu \mathrm{M} \mathrm{MT}=\mathrm{ND}(\mathrm{H} / \mathrm{R})$ treated with $10 \mu \mathrm{M}$ Mito-Tempo; DM (H/R) $+10 \mu \mathrm{M} \mathrm{MT}=\mathrm{DM}(\mathrm{H} / \mathrm{R})$ treated with $10 \mu \mathrm{M}$ Mito-Tempo. Mean $\pm \mathrm{SD}, 1$-way ANOVA, and post hoc Bonferroni test. ND, Nondiabetic; H/R, hypoxia/reoxygenation; MT, Mito-Tempo; DM, diabetes mellitus.

selectively in mitochondria. ${ }^{27}$ In the present study, we found that administration of MT significantly inhibited the generation of endothelial mROS induced by CP-H/R.

The in vitro $\mathrm{CP}-\mathrm{H} / \mathrm{R}$ model was used to investigate the effects of $\mathrm{CP}-\mathrm{H} / \mathrm{R}$ on coronary endothelium-dependent dilatation in mice with or without DM. Our results demonstrated that the impaired coronary dilation function is associated with a significant increase in endothelial mROS. Multiple studies suggested MT reduced adverse changes in a variety of disorders by inhibiting high levels of 
Use of mROS Inhibitor to Protect Coronary Endothelial Function

Methods: The coronary microvessels or endothelial cells harvested from non-diabetic (ND) and diabetic

$(\mathrm{DM})$ mice $(n=44)$ from were treated with or without the mROS inhibitor Mito-Tempo (MT, 0-10 $\mu \mathrm{M})$ during CP-H/R.
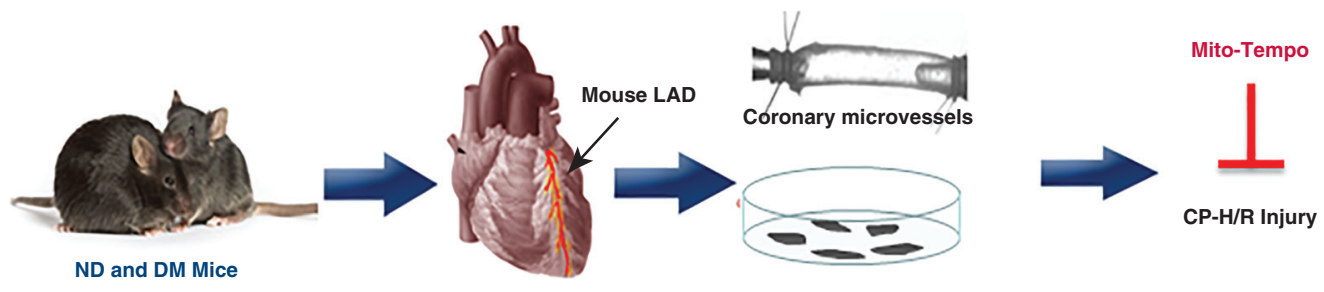

A

Endothelial cells

Results: Mito-Tempo $(10 \mu \mathrm{M})$ increased endothelial SK channel activity and NO signaling pathways, resulting in improving coronary endothelial function, Endothelium-derived hyperpolarization and coronary relaxation response to the SK activator NS309 in the setting of CP-H/R.
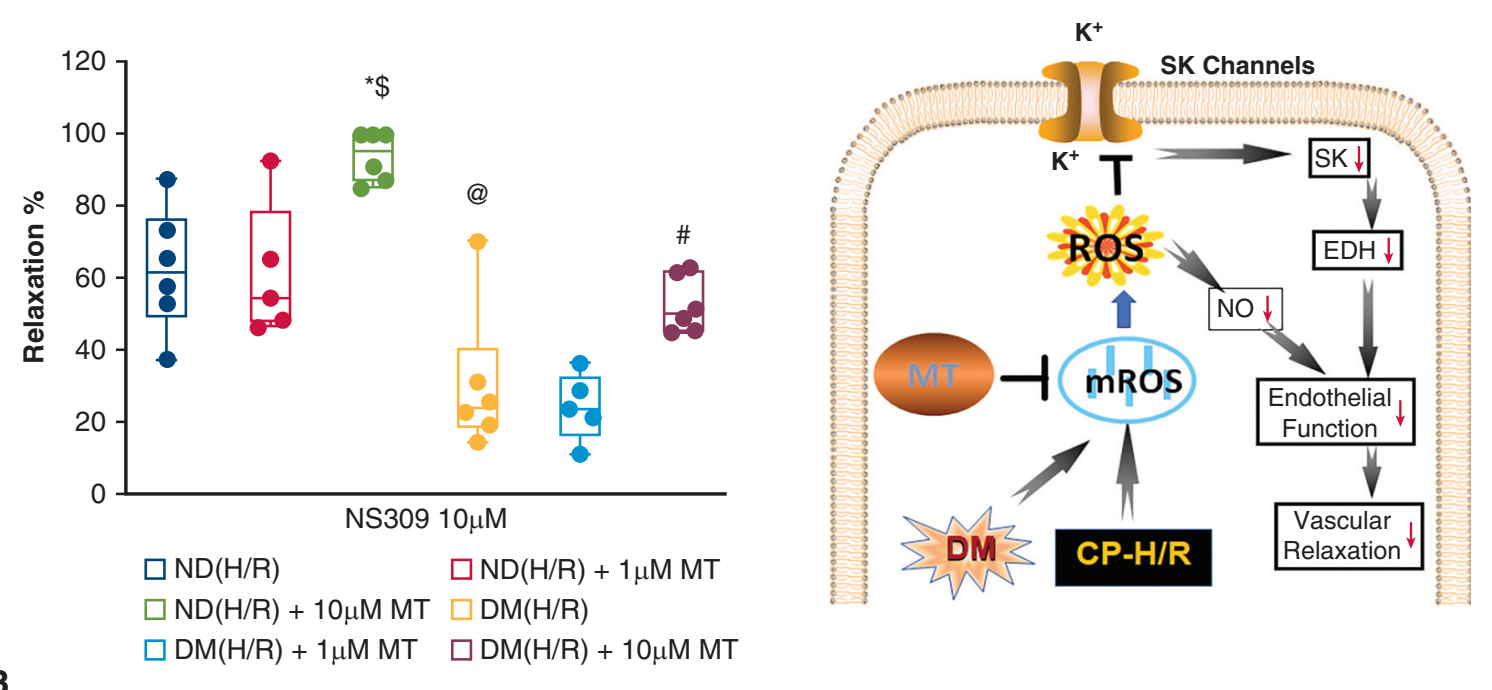

B

Implications: The novel strategies to protect the coronary endothelium in the setting of cardiovascular surgery, such as the inhibition of mROS have considerable short-term and long-term clinical implications.

C

FIGURE 7. Research summary concerning that treatment with the mROS inhibitor, MT increases endothelial SK currents and NO signaling pathways, resulting in improving coronary endothelial function, EDH, and coronary relaxation in the setting of CP-H/R in mice with or without DM. ND $(\mathrm{H} / \mathrm{R})=\mathrm{ND}$ treated by hypoxia/reoxygenation, ND $(\mathrm{H} / \mathrm{R})+1 \mu \mathrm{M} \mathrm{MT}=\mathrm{ND}(\mathrm{H} / \mathrm{R})+1 \mu \mathrm{M} \mathrm{MT} ; \mathrm{ND}(\mathrm{H} / \mathrm{R})+10 \mu \mathrm{M} \mathrm{MT}=\mathrm{ND}(\mathrm{H} / \mathrm{R})+10 \mu \mathrm{M} \mathrm{MT} ;$ $\mathrm{DM}(\mathrm{H} / \mathrm{R})=\mathrm{DM}$ treated by hypoxia/reoxygenation; DM $(\mathrm{H} / \mathrm{R})+1 \mu \mathrm{M} \mathrm{MT}=\mathrm{DM}+1 \mu \mathrm{M} \mathrm{MT} ; \mathrm{DM}(\mathrm{H} / \mathrm{R})+10 \mu \mathrm{M} \mathrm{MT}=\mathrm{DM}+10 \mu \mathrm{M} \mathrm{MT}$. ${ }^{\circledR} P=.0002, \mathrm{ND}(\mathrm{H} / \mathrm{R})$ versus DM $(\mathrm{H} / \mathrm{R}) ; * P=.002, \mathrm{ND}(\mathrm{H} / \mathrm{R})+10 \mu \mathrm{M}$ MT versus ND $(\mathrm{H} / \mathrm{R}) ;{ }^{\#} P=.0329$, DM $(\mathrm{H} / \mathrm{R})+10 \mu \mathrm{M} \mathrm{MT}$ versus DM $(\mathrm{H} / \mathrm{R}) ;{ }^{\$} P<.0001, \mathrm{ND}(\mathrm{H} / \mathrm{R})+10 \mu \mathrm{M}$ MT versus DM $(\mathrm{H} / \mathrm{R})+10 \mu \mathrm{M} \mathrm{MT} ; \mathrm{n}=5$-6/group, mean $\pm \mathrm{SD}$, 2-way ANOVA repeated measurement. $m R O S$, Mitochondrial ROS; $C P-H / R$, cardioplegic hypoxia/reoxygenation; $L A D$, left anterior descending artery; $S K$, small conductance calciumactivated potassium; $N O$, nitric oxide; $R O S$, reactive oxygen species; $E D H$, endothelial-derived hyperpolarization.

mROS. ${ }^{27-29}$ Therefore, we further investigated the effects of MT on coronary vasodilation of ND and DM vessels in the setting of $\mathrm{CP}-\mathrm{H} / \mathrm{R}$. Our results demonstrate that $\mathrm{MT}$ $(10 \mu \mathrm{M})$ significantly improves the recovery of coronary endothelium-dependent relaxation in both ND and DM vessels. These findings clearly suggest that coronary endothelial dysfunction after CP-H/R is at least in part induced by mROS, and MT used during CP-H/R may protect coronary vasculature.

There are 4 subtypes of SK channels: SK1 (KCa2.1), SK2 (KCa2.2), SK3 (KCa2.3), and SK4 (SK3.1, IK). SK1 and SK2 mainly present in the neuronal cells. SK2 is also predominately expressed in the cardiomyocytes. SK2 presents in the endothelial nuclei instead of plasma membrane. ${ }^{38}$ 
SK3 and SK4 (IK) are predominately in the endothelial cells, which are mainly responsible for EDHF-induced endothelial hyperpolarization and microvascular relaxation. ${ }^{12,16}$ In the current study, we found that $\mathrm{CP}-\mathrm{H} / \mathrm{R}$ with or without DM did not change SK3/SK4 protein expression in the endothelial cells, and treatment with MT failed to affect the SK3/SK4 protein expression. It suggests that MT may affect SK activity instead of the protein expression amount. We found that MT significantly increased endothelial SK channel currents in the setting of CP-H/R in ND and DM cells. Thus, the MT-induced upregulation of endothelial SK activity contributes to its improvement of coronary relaxation by the selective SK activator NS309 in the setting of CP-H/R. However, the improvement of endothelial function by MT can be mediated by cellular/molecular mechanisms other than activation of SK channels. This notion is supported by our finding that MT also improves the vasorelaxation induced by endothelial NO-dependent vasodilator ADP, which suggests that NO signaling pathways may be synergistically involved in MT-improved vascular relaxation in the setting of CP-H/R.

The endothelial hyperpolarization induced by SK activation is directly propagated to the underlying vascular smooth muscle cells via myoendothelial coupling, which leads to the closure of voltage-gated $\mathrm{Ca}^{2+}$ channels and the subsequent vasodilation. ${ }^{39} \mathrm{SK}$ channel is voltageindependent and $\mathrm{Ca}^{2+}$-activated at submicromolar concentrations of intracellular $\mathrm{Ca}^{2+}(400-800 \mathrm{nM})$ in the endothelium. ${ }^{40}$ The current study and others demonstrate that low intracellular $\mathrm{Ca}^{2+}\left(\mathrm{Ca}^{2+}\right.$ free $)$ or high intracellular $\mathrm{Ca}^{2+}(>2 \mu \mathrm{M})$ inactivated or reduced endothelial SK channel activity, particularly in the presence of high concentration of $\mathrm{Mg}^{2+} .{ }^{40}$ In the current study, we observed that $\mathrm{H} / \mathrm{R}$ caused intracellular $\mathrm{Ca}^{2+}$ overload in both ND and DM cells and coincided with the decreased endothelial SK currents. It is possible that the CP solution containing high $\mathrm{K}^{+}(16-25 \mathrm{mM})$ and $\mathrm{Mg}^{2+}(12 \mathrm{mM})$ in the setting of $\mathrm{CP}-\mathrm{H} / \mathrm{R}$ may significantly cause intracellular $\mathrm{Ca}^{2+}$ overload, resulting in the inactivation of endothelial SK channels. In addition, the metabolic alteration in the enhanced activation/expression of Nox, PKC, and $\mathrm{NADH}^{7,19}$ during DM or CP-H/R may also reduce SK channel sensitivity to $\mathrm{Ca}^{2+}$ and cause the channel internalization of the damaged endothelial cells.

The inactivation of SK channels may contribute to the $\mathrm{CP}-\mathrm{I} / \mathrm{R}$ and DM-induced endothelial dysfunction in the human coronary arterioles. ${ }^{8,15,16}$ Nicotinamide adenine dinucleotide phosphate oxidase 2 (Nox)-dependent ROS overproduction, which could downregulate whole-cell $\mathrm{K}^{+}$ currents, was associated with the damaged SK channels. ${ }^{41}$ Our recent study found that endothelial SK channel function was regulated by the ratio of $\mathrm{NADH}$ and $\mathrm{NAD}^{+}$, and the increase of intracellular NADH in the coronary endothelial cells caused a significant decrease in endothelial
SK channel currents. ${ }^{19}$ These findings suggest that the inactivation of SK channels in CP-H/R may be caused by the overproduction of ROS. More evidence was shown in this study. Coronary dilatation and endothelial SK currents induced by the selective SK channel activators were reduced in both ND and DM MHECs after CP-H/R, whereas MT significantly improved coronary vasorelaxation and SK channel currents, suggesting that MT enhanced the SK channel function by reducing mROS.

\section{Study Limitations}

There are several limitations in the current study. First, whether MT works specifically through SK3 or SK4 (IK) needs to be further studied. Second, this obese/type $2 \mathrm{DM}$ mouse model has been widely used for studying diabetic complications with chronic hyperglycemia. Although it successfully developed chronic hyperglycemia, the blood glucose levels of the DM mice were higher than those of patients with poorly controlled DM (250-350 mg/dL). Third, the current study did not show any significant differences in relaxation response to the endotheliumindependent vasodilator SNP between ND and DM or the control and MT treatment groups. Further work is needed to address the effect of MT on vascular smooth muscle cells under DM and CP-H/R conditions. Fourth, it is well established that the metabolites such as NADH, Nox, PKC, COX-2, and mROS are mutually stimulated during CP-H/ $\mathrm{R}$ and DM. Therefore, future study should focus on those signaling pathways responsible for MT-enhanced SK channel activity and endothelial protection. Fifth, the impact of $\mathrm{NO}, \mathrm{PGI}_{2}$, and $\mathrm{EDHF}$ interactions on the MT-induced endothelial protection needs to be further elucidated. Finally, the in vitro cell/microvessel findings should be further investigated in an in vivo model of $\mathrm{CP} / \mathrm{CPB}$ to confirm the cardiovascular protective effects of MT treatment.

\section{CONCLUSIONS}

Acute administration of MT improves endotheliumdependent vasorelaxation and endothelial SK channel function in the setting of $\mathrm{CP}-\mathrm{H} / \mathrm{R}$ or $\mathrm{DM}$ by decreasing mROS (Figure 7). This investigation into the mROS impact of CP-H/R in SK channel activity and endothelial function in both ND and DM mice with translational research models may be a fundamental step to connect the bench and the bedside. Our findings suggest that mROS may be a novel therapeutic target to treat vascular complications of $\mathrm{CP}-\mathrm{I} / \mathrm{R}$, especially in patients with poorly controlled DM. These findings may have implications in the recovery of patients early after cardiac surgery (Video 1).

\section{Conflict of Interest Statement}

The authors reported no conflicts of interest. 

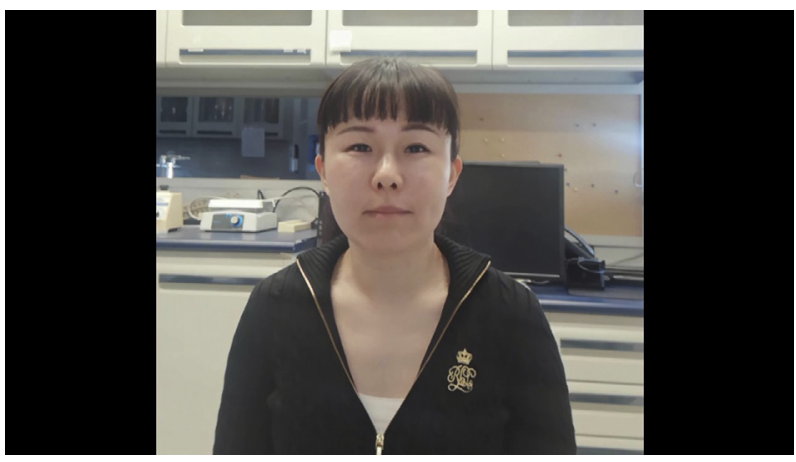

VIDEO 1. The co-first author Dr Song introduces the aims, hypothesis, methods, and results of the current study and explains the selective mROS inhibitor MT-induced coronary endothelial protection and microvascular relaxation in the setting of $\mathrm{CP}-\mathrm{H} / \mathrm{R}$ and $\mathrm{DM}$. Video available at: https://www.jtcvs.org/article/S0022-5223(21)00983-1/fulltext.

The Journal policy requires editors and reviewers to disclose conflicts of interest and to decline handling or reviewing manuscripts for which they may have a conflict of interest. The editors and reviewers of this article have no conflicts of interest.

\section{References}

1. Sarkar M, Prabhu V. Basics of cardiopulmonary bypass. Indian J Anaesthes. 2017;61:760-7.

2. Tempe DK, Saigal D. Myocardial protection during cardiac surgery: An overview of cardioplegia: In: Sehgal R, Trikha A, eds. Yearbook of Anesthesiology7. 2018;(Chapter 24):285-305.

3. Salameh A, Dhein S. Strategies for pharmacological organoprotection during extracorporeal circulation targeting ischemia-reperfusion injury. Front Pharmacol. 2015;6:296.

4. Feng J, Sellke F. Microvascular dysfunction in patients with diabetes after cardioplegic arrest and cardiopulmonary bypass. Curr Opin Cardiol. 2016;31:618-24.

5. Sellke N, Kuczmarski A, Lawandy I, Cole VL, Ehsan A, Singh AK, et al. Enhanced coronary arteriolar contraction to vasopressin in patients with diabetes after cardiac surgery. J Thorac Cardiovasc Surg. 2018;156:2098-107.

6. Robich MP, Araujo EG, Feng J, Osipov RM, Clements RT, Bianchi C, et al. Altered coronary microvascular serotonin receptor expression after coronary artery bypass grafting with cardiopulmonary bypass. J Thorac Cardiovasc Surg. 2010;139:1033-40.

7. Feng J, Liu Y, Chu LM, Singh AK, Dobrilovic N, Fingleton JG, et al. Changes in microvascular reactivity after cardiopulmonary bypass in patients with poorly controlled versus controlled diabetes. Circulation. 2012;126:S73-80.

8. Liu Y, Sellke EW, Feng J, Clements RT, Sodha NR, Khabbaz KR, et al. Calciumactivated potassium channels contribute to human skeletal muscle microvascular endothelial dysfunction related to cardiopulmonary bypass. Surgery. 2008;144: 239-44.

9. Haybar H, Shahrabi S, Rezaeeyan H, Shirzad R, Saki N. Endothelial cells: from dysfunction mechanism to pharmacological effect in cardiovascular disease. Cardiovasc Toxicol. 2019;19:13-22.

10. Shahreza FD. From oxidative stress to endothelial cell dysfunction. J Prev Epidemiol. 2016;1:e04.

11. Vanhoutte PM. Endothelial dysfunction. Circ J. 2009;73:595-601.

12. Félétou M, Vanhoutte PM, Weston AH, Edwards G. EDHF and endothelial potassium channels: IKCa and SKCa. Br J Pharmacol. 2003;140:225; author reply 226.

13. Stankevičius E, Dalsgaard T, Kroigaard C, Beck L, Boedtkjer E, Misfeldt MW, et al. Opening of small and intermediate calcium-activated potassium channels induces relaxation mainly mediated by nitric-oxide release in large arteries and endothelium-derived hyperpolarizing factor in small arteries from rat. J Pharmacol Exp Ther. 2011;339:842-50.

14. Dalsgaard T, Kroigaard C, Bek T, Simonsen U. Role of calcium-activated potassium channels with small conductance in bradykinin-induced vasodilation of porcine retinal arterioles. J Invest Ophthalmol Vis Sci. 2009;50:3819-25.
15. Liu Y, Xie A, Singh AK, Ehsan A, Choudhary G, Dudley S, et al. Inactivation of endothelial small/intermediate conductance of calcium; activated potassium channels contributes to coronary arteriolar dysfunction in diabetic patients. $J$ Am Heart Assoc. 2015;4:e02062.

16. Feng J, Liu Y, Clements RT, Sodha NR, Khabbaz KR, Senthilnathan V, et al Calcium-activated potassium channels contribute to human coronary microvascular dysfunction after cardioplegic arrest. Circulation. 2008;118:S46-51.

17. Yang Q, Huang JH, Man YB, Yao XQ, He GW. Use of intermediate/smal conductance calcium-activated potassium-channel activator for endothelial protection. J Thorac Cardiovasc Surg. 2011;141:501-10. 510.e1.

18. Zhang Z, Shi G, Liu Y, Xing H, Kabakov AY, Zhao AS, et al. Coronary endothelial dysfunction prevented by small-conductance calcium-activated potassium channel activator in mice and patients with diabetes. J Thorac Cardiovasc Surg. 2020;160:e263-80.

19. Liu Y, Kabakov AY, Xie A, Shi G, Singh AK, Sodha NR, et al. Metabolic regulation of endothelial SK channels and human coronary microvascular function. Int J Cardiol. 2020;312:1-9.

20. Kayama Y, Raaz U, Jagger A, Adam M, Schellinger IN, Sakamoto M, et al. Diabetic cardiovascular disease induced by oxidative stress. Int J Mol Sci. 2015;16: 25234-63.

21. Nakamura H, Matoba S, Iwai-Kanai E, Kimata M, Hoshino A, Nakaoka M, et al p53 promotes cardiac dysfunction in diabetic mellitus caused by excessive mitochondrial respiration-mediated reactive oxygen species generation and lipid accumulation. Circ Heart Fail. 2012;5:106-15.

22. Li T-B, Zhang J-J, Liu B, Luo X-J, Ma Q-L, Peng J. Dysfunction of endothelia progenitor cells in hyperlipidemic rats involves the increase of NADPH oxidase derived reactive oxygen species production. Can J Physiol Pharmacol. 2017;95: 474-80.

23. Cheng Z, Shen X, Jiang X, Shan H, Cimini M, Fang P, et al. Hyperhomocysteinemia potentiates diabetes-impaired EDHF-induced vascular relaxation: role of insufficient hydrogen sulfide. Redox Biol. 2018;16:215-25.

24. Kluge MA, Fetterman JL, Vita JA. Mitochondria and endothelial function. Circ Res. 2013;112:1171-88.

25. Trnka J, Blaikie FH, Smith RA, Murphy MP. A mitochondria-targeted nitroxide is reduced to its hydroxylamine by ubiquinol in mitochondria. Free Radic Biol Med. 2008;44:1406-19.

26. Choumar A, Tarhuni A, Lettéron P, Reyl-Desmars F, Dauhoo N, Damasse J, et al Lipopolysaccharide-induced mitochondrial DNA depletion. Antioxid Redox Signal. 2011;15:2837-54.

27. Patil NK, Parajuli N, MacMillan-Crow LA, Mayeux PR. Inactivation of rena mitochondrial respiratory complexes and manganese superoxide dismutase during sepsis: mitochondria-targeted antioxidant mitigates injury. Am J Physiol Renal Physiol. 2014;306:F734-43.

28. Wang A, Keita ÅV, Phan V, McKay CM, Schoultz I, Lee J, et al. Targeting mitochondria-derived reactive oxygen species to reduce epithelial barrier dysfunction and colitis. Am J Pathol. 2014;184:2516-27.

29. Dikalova AE, Bikineyeva AT, Budzyn K, Nazarewicz RR, McCann L, Lewis W, et al. Therapeutic targeting of mitochondrial superoxide in hypertension. Circ Res. 2010;107:106-16.

30. Bers DM, Patton CW, Nuccitelli R. A practical guide to the preparation of $\mathrm{Ca}(2+)$ buffers. Methods Cell Biol. 2010;99:1-26.

31. Sellke FW, Shafique T, Ely DL, Weintraub RM. Coronary endothelial injury after cardiopulmonary bypass and ischemic cardioplegia is mediated by oxygenderived free radicals. Circulation. 1993;88:II395-400.

32. Hiratzka LF, Eastham CL, Carter JG, Moyers JR, Elliott DR, Doty DB, et al. The effects of cardiopulmonary bypass and cold cardioplegia on coronary flow velocity and the reactive hyperemic response in patients and dogs. Ann Thorac Surg. 1988;45:474-81.

33. Tofukuji M, Stahl GL, Agah A, Metais C, Simons M, Sellke FW. Anti-C5a monoclonal antibody reduces cardiopulmonary bypass and cardioplegia-induced coronary endothelial dysfunction. J Thorac Cardiovasc Surg. 1998;116:1060-8.

34. Zhang J, Wang X, Vikash V, Ye Q, Wu D, Liu Y, et al. ROS and ROS-mediated cellular signaling. Oxid Med Cell Longev. 2016;2016:4350965.

35. Forrester SJ, Kikuchi DS, Hernandes MS, Xu Q, Griendling KK. Reactive oxygen species in metabolic and inflammatory signaling. Circ Res. 2018;122: $877-902$.

36. He L, He T, Farrar S, Ji L, Liu T, Ma X. Antioxidants maintain cellular redox homeostasis by elimination of reactive oxygen species. Cell Physiol Biochem 2017:44:532-53.

37. Dhalla NS, Elmoselhi AB, Hata T, Makino N. Status of myocardial antioxidants in ischemia-reperfusion injury. Cardiovasc Res. 2000;47:446-56. 
38. Liu Y, Cole V, Lawandy I, Ehsan A, Sellke FW, Feng J. Decreased coronary arteriolar response to $\mathrm{KCa}$ channel opener after cardioplegic arrest in diabetic patients. Mol Cell Biochem. 2018;445:187-94.

39. Yang JZ, Clark JW, Bryan RMJ, Robertson CS. Mathematical modeling of the nitric oxide/cGMP pathway in the vascular smooth muscle cell. Am J Physiol Heart Circ Physiol. 2005;289:H886-97.

40. Ledoux J, Bonev AD, Nelson MT. Ca2+-activated K+ channels in murine endothelial cells: block by intracellular calcium and magnesium. J Gen Physiol. 2008; 131:125-35.

41. Chen J, Gao Q, Jiang L, Feng X, Zhu X, Fan X, et al. The NOX2-derived reactive oxygen species damaged endothelial nitric oxide system via suppressed $\mathrm{BKCa} /$ SKCa in preeclampsia. Hypertens Res. 2017;40:457-64.
Key Words: cardiac surgery, cardioplegia, cardioplegic arrest, cardioplegic hypoxia and reoxygenation, cardioplegic ischemia and reperfusion, cardiopulmonary bypass, coronary endothelial function, coronary endotheliumdependent vasodilation, coronary microcirculation, diabetes, endothelial function, ion channels, ischemiareperfusion, mitochondria, mitochondrial reactive oxygen species, potassium channels, reactive oxygen species, small conductance calcium-activated potassium channels 


\section{APPENDIX E1. METHODS}

\section{Mouse Heart Tissue Collection}

Each mouse was anesthetized by inhaled isoflurane before heart harvest. A U-shape incision was made for cutting both skin and peritoneum that begins at the navel area and extends up to the front legs. Then the chest cavity was opened by making an incision in the diaphragm and cutting the rib cage on both sides. The heart was harvested by gently lifting at the apex and cutting the great vessels. The excised heart was immediately placed into cold $\left(4^{\circ} \mathrm{C}\right)$ Krebs buffer $\left(119 \mathrm{NaCl}, 25 \mathrm{NaHCO}_{3}, 4.6 \mathrm{KCl}, 1.2\right.$ $\mathrm{KH}_{2} \mathrm{PO}_{4}, 1.2 \mathrm{MgSO}_{4}, 1.8 \mathrm{CaCl}_{2}, 11$ glucose, in $\mathrm{mM}, \mathrm{pH}$ 7.4) for microvessel study or cold cell culture medium for cell isolation, respectively. The experimental protocols/ groups are summarized in the Figure E1.

\section{Microvessel Dissection and Stabilization}

The distal portion of the left anterior descending artery (100-150 $\mu \mathrm{m}$ in diameter) was dissected from the isolated mouse heart as previously described. ${ }^{\mathrm{E} 1}$ Then, the microvessel was cannulated with 2 glass micropipettes and pressurized in a no-flow state in a microvessel organ chamber containing aerated $\left(\begin{array}{lllll}95 \% & \mathrm{O}_{2}, & 5 \% & \mathrm{CO}_{2}\end{array}\right)$ Krebs buffer solution, and maintained at $37^{\circ} \mathrm{C}$. After a 60-minute stabilization period in the chamber, we studied the pathophysiologic change by $\mathrm{H} / \mathrm{R}$ injury stimulation.

\section{CP-H/R Model of Endothelial Cells}

Mouse heart endothelial cells (MHECs) isolated from the harvested heart were cultured in EGM-2 MV medium (Lonza Biosciences, Alpharetta, Ga). For developing CP$\mathrm{H} / \mathrm{R}$ model, MHECs were placed in the sealed chamber, filled by high-concentration of nitrogen $\left(95 \% \quad \mathrm{~N}_{2}+5 \%\right.$ $\mathrm{CO}_{2}$ ) for 3 hours, and then reoxygenated for 2 hours by transferring cells into the normoxic culture incubator. Mito-Tempo $(10 \mu \mathrm{M})$ was added to the culture medium 30 minutes before $\mathrm{H} / \mathrm{R}$. ${ }^{\mathrm{E} 1}$

\section{Measurement of Intracellular Calcium}

Endothelial cells were loaded with $1 \mu \mathrm{M}$ Rhod-2 (Thermo Fisher Scientific) for 30 minutes by incubation in bath solution containing $5 \mathrm{KCl}, 140 \mathrm{NaCl}, 2 \mathrm{MgCl}_{2}, 1$ $\mathrm{CaCl}_{2}, 10 \mathrm{HEPES}, 30$ glucose (in mM). Rhod-2 AM was excited using a 545-nm laser and the fluorescence emission was collected at 578-nm wavelengths. Rhod-2 fluorescence signal was converted to intracellular $\mathrm{Ca}^{2+}$ concentration using the following equation: $\left[\mathrm{Ca}^{2+}\right]_{\mathrm{i}}=\mathrm{Kd}\left(\mathrm{F}-\mathrm{F}_{\min }\right) /\left(\mathrm{F}_{\max }{ }^{-}\right.$ $\mathrm{F})$, where $\mathrm{Kd}$ Rhod- $2=1.58 \mu \mathrm{M}$ and $\mathrm{F}_{\min }=\mathrm{F}_{\max } / 15$. ${ }^{\mathrm{E} 2, \mathrm{E} 3}$ $\mathrm{F}_{\text {max }}$ was determined by adding $100 \mu \mathrm{M}$ Rhod-2 to the 1$\mathrm{mM} \mathrm{Ca}{ }^{2+}$ bath solution and measuring the Rhod-2 fluorescence. The fluorescence quantification was obtained using ImageJ (National Institutes of Health, Bethesda, Md) software.

\section{Electrophysiological Study of Endothelial Cell $\mathbf{K}^{+}$ Currents}

The patch clamp recording system are depicted in the Figure E2. Patch clamp recording techniques were used to measure $\mathrm{K}^{+}$currents in the whole cell patch-clamp configurations, as described in detail previously. ${ }^{\mathrm{E} 1}$ The primarily cultured MHECs were washed twice with $\mathrm{Ca}^{2+}$-free DMEM. Whole cell $\mathrm{K}^{+}$currents were recorded with Axon Axopatch-200B amplifier, Axon Digidata 1550B A/ D converter, and pClamp 11 software (all by Molecular Devices, Foster City, Calif) in the voltage-clamp mode. The bath solution containing $5 \mathrm{KCl}, 140 \mathrm{NaCl}, 2 \mathrm{MgCl}_{2}, 1$ $\mathrm{CaCl}_{2}, 10 \mathrm{HEPES}, 30$ glucose (in mM, pH 7.4, 22 ${ }^{\circ} \mathrm{C}$ ). The patch pipette (1-3 M $\Omega$ ) was filled with the pipette solution containing $20 \mathrm{KCl}, 8 \mathrm{NaCl}, 110 \mathrm{~K}$-Aspartate, 8.5 $\mathrm{CaCl}_{2}, 1 \mathrm{MgCl}_{2}, 10 \mathrm{HEPES}, 0.01$ Niflumic acid, and 10 BAPTA (in mM, pH 7.2, with calculated free $\mathrm{Ca}^{2+} 400$ nmol/L). For $\mathrm{Ca}^{2+}$ free (low $\mathrm{Ca}^{2+}$ group) pipette solution, no $\mathrm{CaCl}_{2}$ was added. For high $\mathrm{Ca}^{2+}(2 \mu \mathrm{M})$ pipette solution, $9.7 \mathrm{mM} \mathrm{CaCl}_{2}$ was added. The free $\mathrm{Ca}^{2+}$ concentration was calculated by using Maxchelator as described previously in detail. $^{\mathrm{E} 4}$

Current voltage recording conditions for $\mathrm{K}^{+}$currents were achieved by stepping in $20 \mathrm{mV}$ increments from a holding potential $-50 \mathrm{mV}$ by $150 \mathrm{~ms}$ test pulses in the range between -100 to $+100 \mathrm{mV}$. $\mathrm{K}^{+}$currents were expressed as current density (current divided by cell membrane capacitance). Low-pass filter frequency was $2 \mathrm{kHz}$ and sampling rate was $10 \mathrm{kHz}$. Current time recording conditions for $\mathrm{K}^{+}$currents were obtained by holding potential at +100 $\mathrm{mV}$. The selective SK activator NS309 on the whole cell $\mathrm{K}^{+}$currents were examined, and then both SK2/SK3 blocker apamin $\left(10^{-7} \mathrm{M}\right)$ and the SK4(IK) blocker TRAM34 $\left(10^{-6} \mathrm{M}\right)$ were applied for testing the specificity of SK channel activation. ${ }^{\mathrm{E} 1, \mathrm{E} 5, \mathrm{E} 6}$

\section{Western Blotting}

The methods for whole-cell protein purification, Western blotting, and imaging quantification have been described

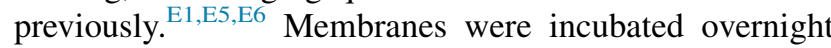
at $4^{\circ} \mathrm{C}$ with primary antibodies against SK3 and SK4 (Alomone Labs, Jerusalem, Israel). After washing with TBST, membranes were incubated with secondary antibody conjugated to horseradish peroxidase. All membranes were also incubated with glyceraldehyde-3phosphate dehydrogenase (Cell Signaling Technology, Danvers, Mass) as loading controls.

\section{Measurement of Mitochondrial Reactive Oxygen Species}

MHECs were stained with $5 \mu \mathrm{M}$ MitoSox Red and 100 nM MitoTracker Green FM (Invitrogen, Waltham, Mass) according to the manufacture's protocol and previously studied. ${ }^{\mathrm{E} 6}$ Then cells were counter stained with $5 \mu \mathrm{g} / \mathrm{mL}$ 
Hoechst 33342 for 10 minutes. Images were taken on a Zeiss LSM710 confocal microscope (Carl Zeiss GmbH, Jena, Germany). The mean values of the whole cell fluorescence of MitoSOX Red were obtained with Image J software. ${ }^{\mathrm{E} 6}$

\section{RESULTS}

\section{Characteristics of DM and ND Mice}

The age, body weight, and blood glucose levels of nondiabetic (ND) and diabetic (DM) mice are summarized in Figure E3.

\section{Dose- and Endothelium-Dependent Relaxation Responses to NS309 and ADP in the Mouse Small Coronary Arteries}

Following $\mathrm{CP}-\mathrm{H} / \mathrm{R}$, the endothelium-dependent relaxation responses of mouse diabetic vessels to NS309 (Figure E4, A) and ADP (Figure E4, B) were significantly decreased compared with that of nondiabetic mice in a dose-dependent fashion. Treatment with MT $(10 \mu \mathrm{M})$ improved the recovery of endothelium-dependent relaxation responses to the SK activator NS309 and ADP in DM and ND mice.

\section{Dose- and Endothelium-Independent Relaxation Responses to SNP in the Mouse Small Coronary Arteries}

There were no significant differences in the dose- and endothelium-independent relaxation responses to SNP after $\mathrm{CP}-\mathrm{H} / \mathrm{R}$ between ND and DM groups. There were no significant changes in the dose-dependent relaxation response to
SNP after MT $(10 \mu \mathrm{M})$ treatment between ND and DM groups (Figure $\mathrm{E} 4, C$ ).

\section{MT $(10 \mu \mathrm{M})$ Enhanced SK Channel Currents of MHECs in H/R Model From ND and DM Mice}

Administration of NS309 significantly increased the total $\mathrm{K}^{+}$currents of MHECs in H/R model both types of cell/ treatment from ND and DM mice $(P=.071$ and $P=$ .0494; Figure E5, $A$ and $C$ ), which also seen in ND and DM treatment with MT $(10 \mu \mathrm{M})$ groups $(P=.0027$ and $P$ $<.0001$; Figure E5, $B$ and $D$ ). Subsequent application of apamin $\left(10^{-7} \mathrm{M}\right)$ and TRAM34 $\left(10^{-6} \mathrm{M}\right)$ abolished NS309-induced effects on $\mathrm{K}^{+}$currents in both cell/treatment types.

\section{E-References}

E1. Zhang Z, Shi G, Liu Y, Xing H, Kabakov AY, Zhao AS, et al. Coronary endothelial dysfunction prevented by small-conductance calcium-activated potassium channel activator in mice and patients with diabetes. J Thorac Cardiovasc Surg. 2020;160:e263-80.

E2. Escobar AL, Velez P, Kim AM, Cifuentes F, Fill M, Vergara JL. Kinetic properties of DM-nitrophen and calcium indicators: rapid transient response to flash photolysis. Pflugers Arch. 1997;434:615-31.

E3. Trafford AW, Diaz ME, O'Neill SC, Eisner DA. Comparison of subsarcolemmal and bulk calcium concentration during spontaneous calcium release in rat ventricular myocytes. J Physiol. 1995;488(Pt 3):577-86.

E4. Bers DM, Patton CW, Nuccitelli R. A practical guide to the preparation of $\mathrm{Ca}(2+)$ buffers. Methods Cell Biol. 2010;99:1-26.

E5. Liu Y, Xie A, Singh AK, Ehsan A, Choudhary G, Dudley S, et al. Inactivation of endothelial small/intermediate conductance of calcium activated potassium channels contributes to coronary arteriolar dysfunction in diabetic patients. $J$ Am Heart Assoc. 2015:4:e002062.

E6. Liu Y, Kabakov AY, Xie A, Shi G, Singh AK, Sodha NR, et al. Metabolic regulation of endothelial SK channels and human coronary microvascular function. Int J Cardiol. 2020;312:1-9. 
Microvessel Groups

\begin{tabular}{|l|l|}
\hline Group description & $\begin{array}{l}\text { Abbreviation, } \\
\text { number }\end{array}$ \\
\hline $\begin{array}{l}\text { ND mouse coronary microvessels } \\
\text { were subjected to CP-H/R without } \\
\text { MT treatment }\end{array}$ & $\mathrm{ND}(\mathrm{H} / \mathrm{R}), \mathrm{n}=6$ \\
\hline $\begin{array}{l}\text { ND mouse coronary microvessels were } \\
\text { subjected to CP-H/R with } 1 \mu \mathrm{M} \text { MT treatment }\end{array}$ & $\mathrm{ND}(\mathrm{H} / \mathrm{R})+1 \mu \mathrm{M} \mathrm{MT}, \mathrm{n}=5$ \\
\hline $\begin{array}{l}\text { ND mouse microvessels were subjected to } \\
\text { CP-H/R with } 10 \mu \mathrm{M} \text { MT treatment }\end{array}$ & $\mathrm{ND}(\mathrm{H} / \mathrm{R})+10 \mu \mathrm{M} \mathrm{MT}, \mathrm{n}=6$ \\
\hline $\begin{array}{l}\text { DM mouse microvessels were subjected to } \\
\text { CP-H/R without MT treatment }\end{array}$ & $\mathrm{DM}(\mathrm{H} / \mathrm{R}), \mathrm{n}=6$ \\
\hline $\begin{array}{l}\text { DM mouse microvessels were subjected to } \\
\text { CP-H/R with } 1 \mu \mathrm{M} \text { MT treatment }\end{array}$ & $\mathrm{DM}(\mathrm{H} / \mathrm{R})+1 \mu \mathrm{M} \mathrm{MT}, \mathrm{n}=5$ \\
\hline $\begin{array}{l}\text { DM mouse microvessels were subjected to } \\
\text { CP-H/R with } 10 \mu \mathrm{M} \text { MT treatment }\end{array}$ & $\mathrm{DM}(\mathrm{H} / \mathrm{R})+10 \mu \mathrm{M} \mathrm{MT}, \mathrm{n}=6$ \\
\hline
\end{tabular}

\section{Endothelial Cell Groups}

\begin{tabular}{|l|l|}
\hline Group description & $\begin{array}{l}\text { Abbreviation, } \\
\text { number }\end{array}$ \\
\hline ND MHECs without H/R or MT treatment & ND \\
\hline $\begin{array}{l}\text { ND MHECs were subjected to H/R without } \\
\text { MT treatment }\end{array}$ & $\mathrm{ND}(\mathrm{H} / \mathrm{R})$ \\
\hline $\begin{array}{l}\text { ND MHECs were subjected to CP-H/R with } \\
10 \mu M \text { MT treatment }\end{array}$ & $\mathrm{ND}(\mathrm{H} / \mathrm{R})+10 \mu \mathrm{M} M T$ \\
\hline $\begin{array}{l}\text { DM MHECs without H/R or MT treatment } \\
\text { DM MHECs were subjected to H/R without } \\
\text { MT treatment }\end{array}$ & $\mathrm{DM}$ \\
\hline $\begin{array}{l}\text { DM MHECs were subjected to CP-H/R with } \\
10 \mu M \text { MT treatment }\end{array}$ & $\mathrm{DM}(\mathrm{H} / \mathrm{R})$ \\
\hline
\end{tabular}

FIGURE E1. Experimental groups. $N D$, Nondiabetic; $C P-H / R$, cardioplegic hypoxia/reoxygenation; $M T$, Mito-Tempo; $D M$, diabetes mellitus; MHEC, mouse heart endothelial cell. 


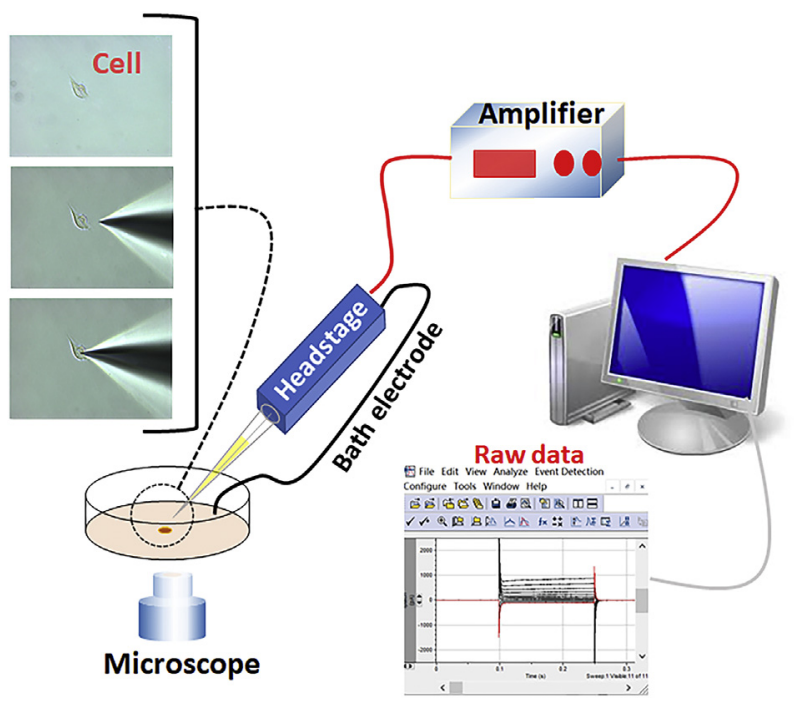

FIGURE E2. The schematic diagram illustrates patch clamp recording system. A glass pipette seals to the membrane of endothelial cell. Once breakthrough of the membrane is achieved by applying light and short suction pulses with a syringe, the analog current signal is amplified and digitized so the signal can be analyzed.

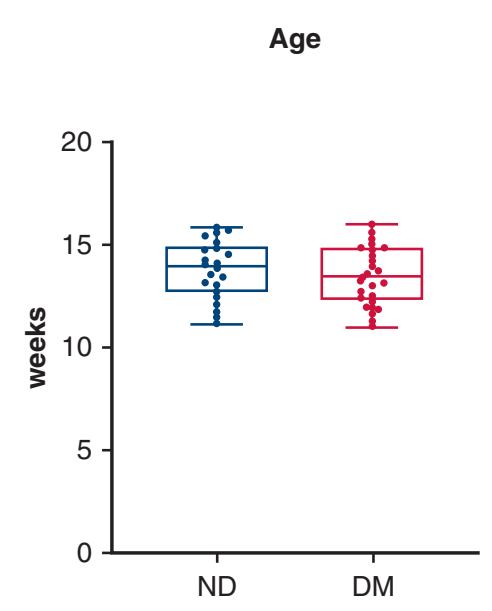

A

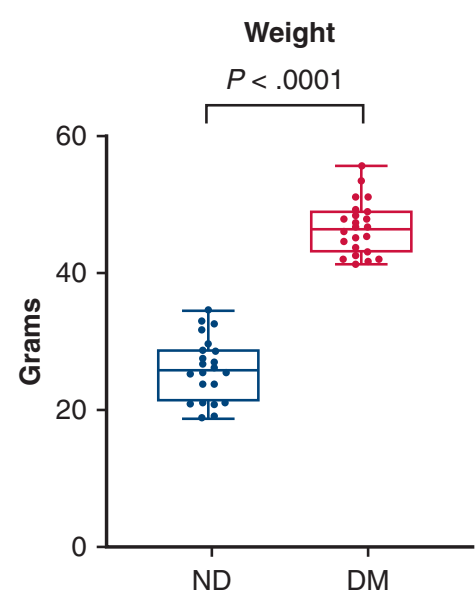

B

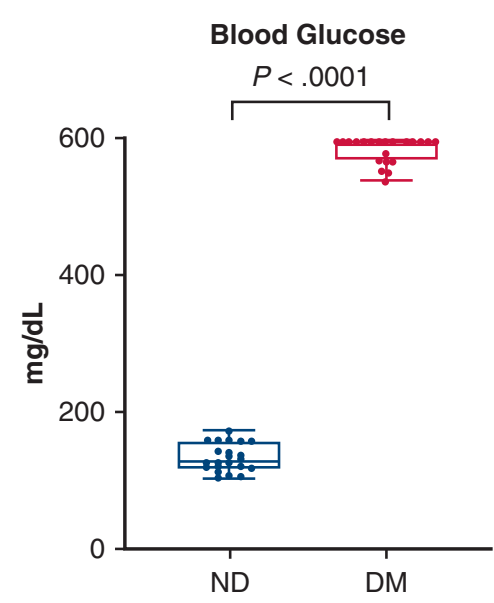

C

FIGURE E3. Characteristics of DM and ND mice. A, Age. B, Body weight $(\mathrm{g}), P=.0001$ DM versus ND. C, Blood glucose (mg/dL), $P=.0001 \mathrm{DM}$ versus ND. $D M$, Diabetes mellitus; $N D$, nondiabetic. 


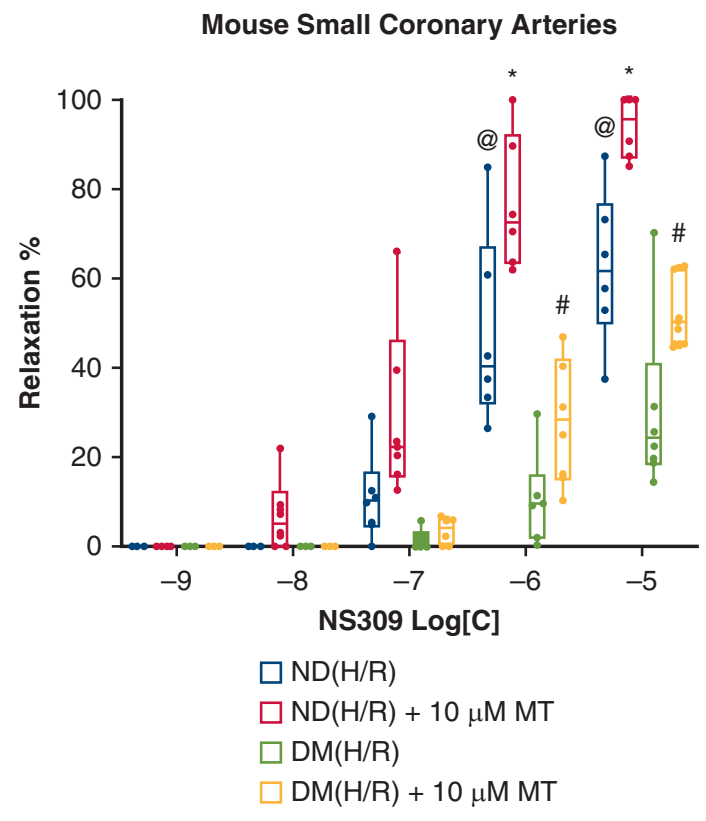

A
Mouse Small Coronary Arteries

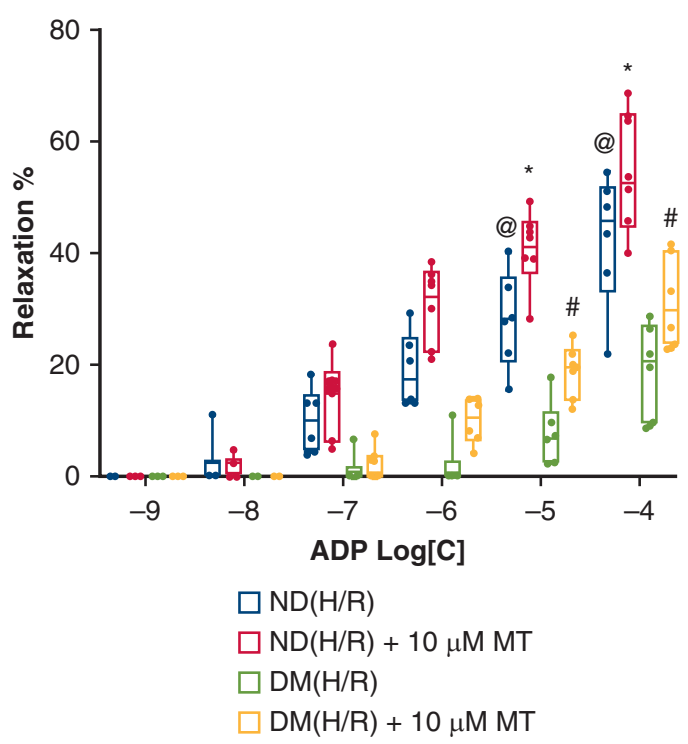

B

Mouse Small Coronary Arteries

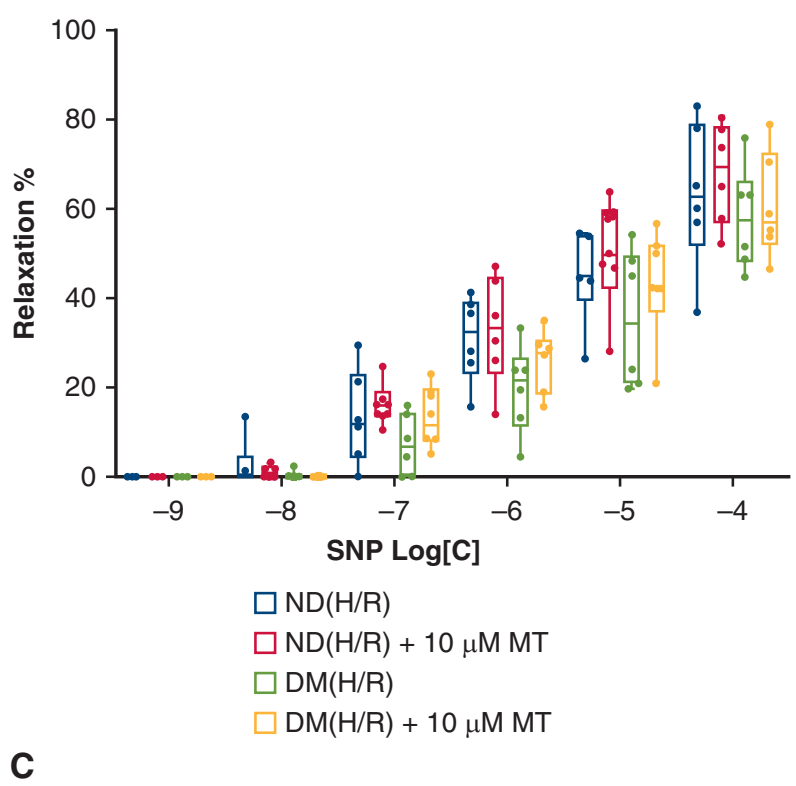

FIGURE E4. Effects of endothelium-dependent vasodilator on mouse heart microvessel vasodilation. A, Dose-dependent vasodilation of mouse heart microvessels of ND $(\mathrm{H} / \mathrm{R})$ and DM $(\mathrm{H} / \mathrm{R})$ with or without MT treatment $(10 \mu \mathrm{M})$ in response to the SK channel activator NS309 $\left(10^{-9}-10^{-5} \mathrm{M}^{-}\right.$, $\mathrm{n}=6$ /group. ${ }^{*} P<.0001\left(\mathrm{NS} 30910^{-6} \mathrm{M}\right), P<.0001\left(\mathrm{NS} 30910^{-5} \mathrm{M}\right), \mathrm{ND}(\mathrm{H} / \mathrm{R})$ versus ND $(\mathrm{H} / \mathrm{R})+10 \mu \mathrm{M} \mathrm{MT} ;{ }^{\#} P=.0284\left(\mathrm{NS} 30910^{-6} \mathrm{M}\right)$; $P=.0043\left(\mathrm{NS} 30910^{-5} \mathrm{M}\right)$, DM (H/R) versus DM (H/R) $+10 \mu \mathrm{M} \mathrm{MT} ;{ }^{\varrho} P<.0001$ (NS309 $\left.10^{-6} \mathrm{M}\right), P<.0001$ (NS309 $\left.10^{-5} \mathrm{M}\right), \mathrm{ND}(\mathrm{H} / \mathrm{R})$ versus $\mathrm{DM}(\mathrm{H} / \mathrm{R})$. B, Dose-dependent vasodilation of mouse small coronary arteries of ND (H/R) and DM (H/R) with or without MT (10 $\mu \mathrm{M})$ treatment in response to the endothelium-dependent vasodilator ADP $\left(10^{-9}-10^{-4} \mathrm{M}\right), \mathrm{n}=6 /$ group. $* P=.0021$ (ADP $\left.10^{-5} \mathrm{M}\right), P=.0062\left(\mathrm{ADP} 10^{-4} \mathrm{M}\right)$, ND (H/R) versus ND $(\mathrm{H} / \mathrm{R})+10 \mu \mathrm{M} \mathrm{MT} ;{ }^{\#} P=.0090\left(\mathrm{ADP} 10^{-5} \mathrm{M}\right), P=.0029\left(\mathrm{ADP} 10^{-4} \mathrm{M}\right), \mathrm{DM}(\mathrm{H} / \mathrm{R})$ versus DM $(\mathrm{H} / \mathrm{R})+10 \mu \mathrm{M} \mathrm{MT} ;{ }^{\circledR} P<.0001\left(\mathrm{ADP} 10^{-5} \mathrm{M}\right), P<.0001$ $\left(\mathrm{ADP} 10^{-4} \mathrm{M}\right)$, ND (H/R) versus DM (H/R). C, Dose-dependent vasodilation of mouse small coronary arteries of ND (H/R) and DM (H/R) with or without MT treatment $(10 \mu \mathrm{M})$ in response to the endothelium-independent vasodilator SNP $\left(10^{-9}-10^{-4} \mathrm{M}\right), \mathrm{n}=6 /$ group. ND $(\mathrm{H} / \mathrm{R})=\mathrm{ND}$ treated by hypoxia/reoxygenation, $\mathrm{DM}(\mathrm{H} / \mathrm{R})=\mathrm{DM}$ treated by hypoxia/reoxygenation, ND $(\mathrm{H} / \mathrm{R})+10 \mu \mathrm{M}$ MT $=\mathrm{ND}(\mathrm{H} / \mathrm{R})+10 \mu \mathrm{M} \mathrm{MT}$, DM $(\mathrm{H} / \mathrm{R})+10 \mu \mathrm{M} \mathrm{MT}=\mathrm{DM}(\mathrm{H} / \mathrm{R})+10 \mu \mathrm{M} \mathrm{MT} . N D$, Nondiabetic; $H / R$, hypoxia/reoxygenation; $M T$, Mito-Tempo; $D M$, diabetes mellitus; $A D P$, Adenosine 5'-diphosphate; $S N P$, sodium nitroprusside. 


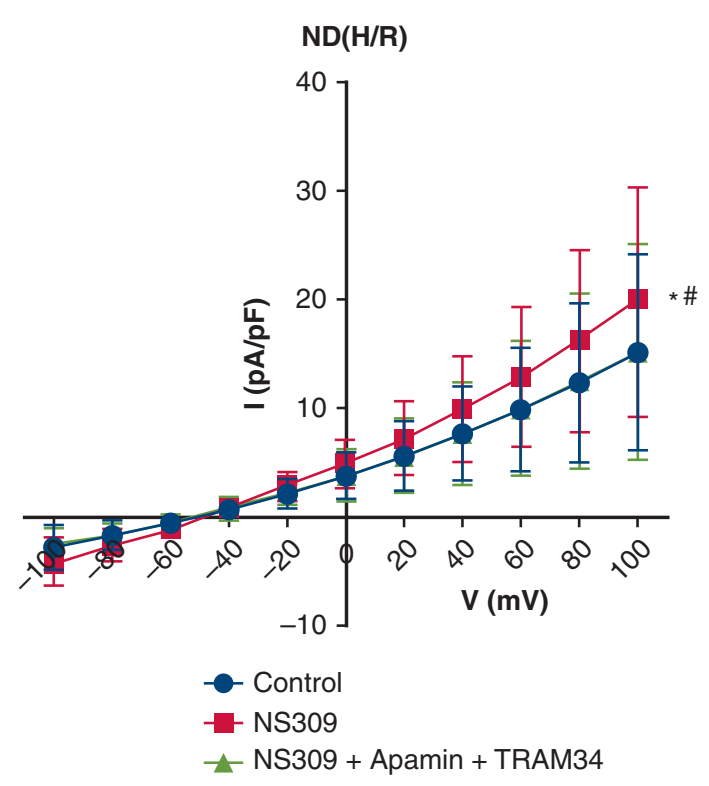

A

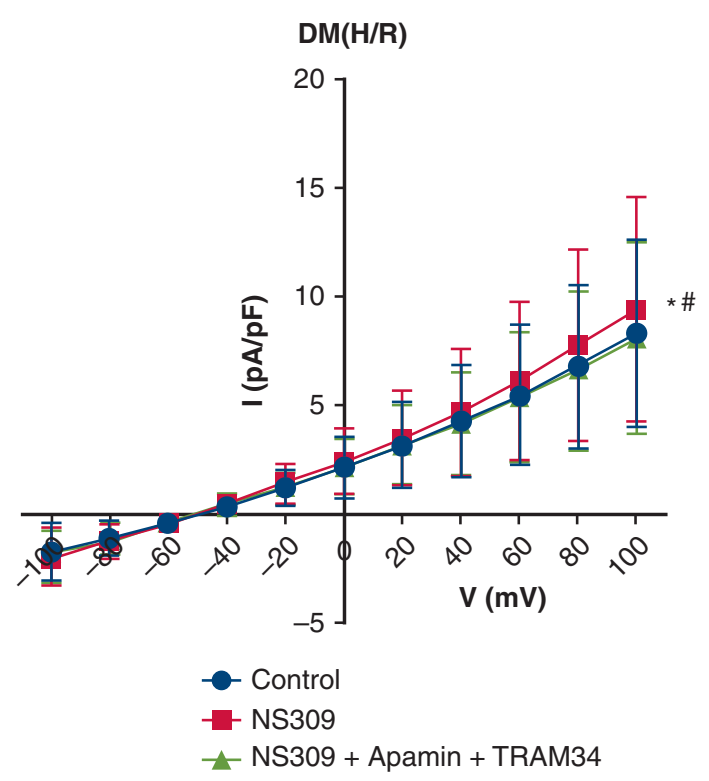

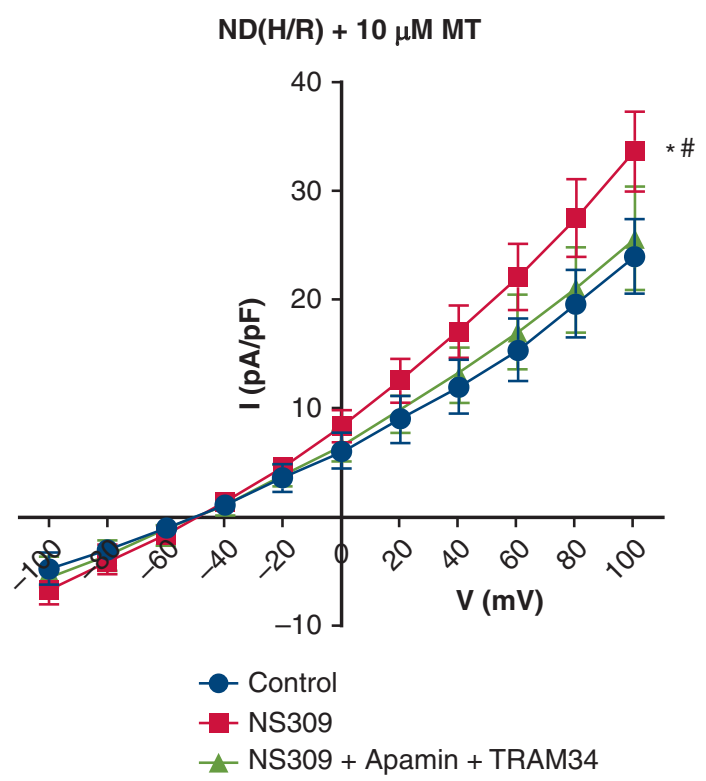

B

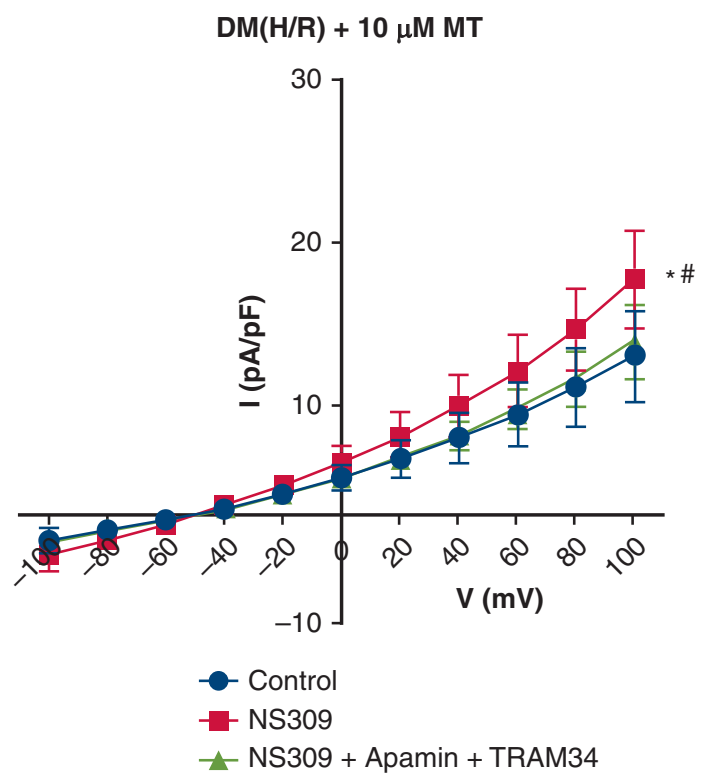

D

FIGURE E5. The data of IV relationship for NS309 and apamin + TRAM34 sensitive currents within each cell/treatment group. MT (10 $\mu$ M) significantly increases SK channel currents of MHECs in H/R model from ND and DM mice. A-D, Effect of the SK channel activator NS309 and SK channel blocker Apamin and TRAM34 on the basal whole-cell $\mathrm{K}^{+}$currents of MHECs in H/R model from ND and DM mice treatment with or without MT. *NS309 versus control, $P=.0071$, ND $(\mathrm{H} / \mathrm{R}) ; P=.0027, \mathrm{ND}(\mathrm{H} / \mathrm{R})+10 \mu \mathrm{M} \mathrm{MT} ; P=.0494$, DM $(\mathrm{H} / \mathrm{R}) ; P<.001$, DM $(\mathrm{H} / \mathrm{R})+10 \mu \mathrm{M}$ MT, \#NS309 versus $\mathrm{NS} 309+$ Apamin + TRAM34, $P=.0061, \mathrm{ND}(\mathrm{H} / \mathrm{R}) ; P=.0018, \mathrm{ND}(\mathrm{H} / \mathrm{R})+10 \mu \mathrm{M} \mathrm{MT} ; P=.038, \mathrm{DM}(\mathrm{H} / \mathrm{R}) ; P=.0005, \mathrm{DM}(\mathrm{H} / \mathrm{R})+10 \mu \mathrm{M} \mathrm{MT}$. $N D$, Nondiabetic; $H / R$, hypoxia/reoxygenation; $M T$, Mito-Tempo; $D M$, diabetes mellitus. 